\title{
Effects of Unconventional Monetary Policy on Financial Institutions
}

\begin{abstract}
Monetary policy affects the real economy in part through its effects on financial institutions. High-frequency event studies show that the introduction of unconventional monetary policy in the winter of 2008-09 had a strong, beneficial impact on banks and, especially, on life insurance companies. I interpret the positive effects on life insurers as evidence that expansionary policy helped to recapitalize the sector by raising the value of legacy assets. Expansionary policy had small positive or neutral effects on banks and life insurers during the period 2010-13. The interaction of low nominal interest rates and administrative costs forced money market funds to waive fees, producing a possible incentive to reach for yield to reduce waivers. I show that money market funds with higher costs did reach for higher returns in 2009-11, but not thereafter. Some private defined-benefit pension funds increased their risk taking beginning in 2009, but again such behavior largely dissipated by 2012. In sum, unconventional monetary policy helped to stabilize some sectors and provoked modest additional risk taking in others. I do not find evidence that riskiness of the financial institutions studied fomented a trade-off between expansionary policy and financial stability at the end of 2013.
\end{abstract}

n the winter of 2008, the Federal Reserve's Federal Open Market

Committee (FOMC) began using a mix of policy instruments unprecedented in its history. This mix expanded to eventually include a target federal funds rate of essentially zero, purchases of Treasury bonds, purchases of agency mortgage-backed securities (from Fannie Mae, Freddie Mac, and Ginnie Mae), purchases of agency bonds, and explicit guidance concerning the future path of the federal funds rate. I refer to this mix of instruments as unconventional monetary policy. The FOMC introduced these policies with the intention of reducing long-term real interest rates, which it believed 
would lead to a stronger economic recovery. ${ }^{1}$ A number of studies have since confirmed the success in reducing long-term rates (Gagnon and others 2010; Krishnamurthy and Vissing-Jorgensen 2011; Campbell and others 2012; Wright 2012).

The introduction of new treatments raises concern about side effects. In the aftermath of one of the worst financial crises in history, a possibly acute side effect involves the health and stability of the financial sector. Indeed, numerous FOMC participants have cited increased risk taking by financial institutions as a potential constraint on their policy choices (Bernanke 2013; Stein 2013a; Fisher 2014). Alternatively, an improving real economy spurred in part by the unconventional policy may have helped to stabilize some financial institutions.

In this paper I discuss four channels through which unconventional monetary policy affects the financial sector. First, reducing the risk-free rate lowers the hurdle rate for risky investment projects. This leads to increased new spending on projects with either lower mean returns or higher variances. Depending on the distribution of newly funded projects, the optimal level of real risk in the economy may change. Financial institutions carry exposure to real project risk through their role as intermediaries between borrowers and savers. Second, unconventional policy may lead some financial institutions to seek higher returns, due to institutional dissatisfaction with low yields. By definition, such "reaching for yield" constitutes an increase in risk taking beyond what the end holders of the risk would prefer. Third, by promoting recovery in the real economy, unconventional policy lowers delinquency and default rates, raises profits, and possibly lowers risk aversion. Higher probability of payoff, higher profits, or less risk aversion each implies higher prices of legacy assets (financial assets already on financial institutions' balance sheets), and this improves solvency. These general equilibrium effects may also benefit financial companies that sell products with a positive income elasticity. Fourth, low interest rates reduce the opportunity cost of holding reserves or collateral. This may generate larger balance sheets and higher leverage at institutions facing binding collateral or reserve requirements, such as banks.

I then turn to evidence drawn from four classes of financial institutions. I use high-frequency event studies to measure the response of credit default swap (CDS) spreads, bond yields, and the equity prices of life insurers

1. See for example the FOMC statement announcing a new round of asset purchases in September 2012 (http://www.federalreserve.gov/newsevents/press/monetary/20120913a.htm). 
and bank holding companies in narrow windows surrounding surprise announcements of policy changes. I study bank holding companies because of their importance to the financial system. For life insurers, the combination of long-term fixed-income liabilities and shorter duration assets may generate a compressed or even negative interest spread at low rates and prompt reaching for yield behavior. On the other hand, many life insurers faced solvency crises in early 2009 , and the legacy corporate and mortgage bonds on their balance sheets would have benefited from expansionary policy. In the event, the initial round of expansionary policy in the winter of 2008-09 had a stabilizing and salutary effect. Life insurer and bank CDS spreads fell, bond yields fell, and stock prices increased immediately following monetary policy announcements, the effect on life insurers being particularly pronounced. Subsequent policy announcements had smaller effects, but expansionary policy continued to benefit the asset prices of life insurers and banks.

Some money market funds had engaged in reaching for yield in late 2007 and 2008, with disastrous consequences following the Lehman Brothers bankruptcy. A low interest rate environment could again provoke such behavior by squeezing funds' ability to cover administrative costs. Indeed, beginning in 2009, funds passed higher gross yields through into higher charged expenses nearly one-for-one, with almost no effect on the net yield received by investors. The high pass-through rate suggests that the funds' operators understood the cost of waiving fees and the potential to avoid such costs by generating higher gross returns-by reaching for yield. In this study, I exploit cross-sectional differences in administrative costs to determine whether such costs pushed funds to increase their risk taking. I do find evidence of high-cost funds pursuing higher gross returns and accepting greater return variance during the 2009-11 period, although the economic magnitudes are small. Such behavior vanished by 2013, when the compression in yields across asset classes left little room for funds to reach for yield.

Finally, I analyze risk taking by private defined-benefit pension funds. Underfunded pension plans have the temptation to reach for yield to avoid making larger contributions. Low interest rates may exacerbate this problem by decreasing the expected return absent additional risk taking. Also, funds with a shorter duration of liabilities following a market downturn have less time to smooth their shortfall, and so may try to reach for yield. I use a difference-in-differences framework with these dimensions of heterogeneity, before and after 2009. Funds with shorter liability duration or worse funding status in 2009 had relative increases both in their 
loadings on the market excess return and in the variance of their returns over 2009-12. Again, however, the reaching for yield appears mostly to have dissipated by 2012. Here as well, the positive effect of unconventional monetary policy on the stock market and the overall economy improved the solvency position of defined-benefit pension funds and their sponsors, helping to counteract any deleterious effect of low interest rates on reaching for yield.

In interpreting these results, it helps to review why policymakers might care about the health of the financial sector, and to clarify the distinction between financial institution risk taking and financial sector stability. Financial institution risk taking involves an active decision by managers to change their risk profile. Low interest rates may spur increased risk taking through the hurdle rate effect, or through reaching for yield. At the end of 2013, the combined gross assets of life insurers, private definedbenefit pension funds, money market funds, and regulated banks exceeded $\$ 24$ trillion. Their attitude toward risk has the potential to affect the market price of risk in the economy. Policymakers may therefore be directly concerned about limiting reaching for yield if it causes risk premia to fall below their first-best level. Conversely, in an application of the theory of the second best, an increase in reaching for yield by some institutions may improve welfare if other distortions (for example, insufficient capital in the financial sector) have resulted in too little risk taking in the economy.

The effect of monetary policy on the stability of the financial sector is a combination of the effects on risk taking and leverage and the general equilibrium effects on legacy asset prices and the economic environment. Recent theoretical work emphasizes the sharply nonlinear effect of financial sector capital on risk premia and lending (He and Krishnamurthy 2013; Brunnermeier and Sannikov 2014). In these models, large contractions in financial sector capital cause capital constraints to bind or set off adverse feedback loops. For example, in a fire sale, an institution's need to de-lever puts downward pressure on the mark-to-market price of assets held at other institutions, which may then set off further deleveraging (Shleifer and Vishny 2011). The rapid economic collapse following the Lehman Brothers bankruptcy highlights these nonlinear dynamics, as well as providing a reminder of the direct link between the health of the financial sector and the Federal Reserve's employment mandate (Chodorow-Reich 2014). Higher risk affects financial sector stability, regardless of whether it stems from first-best reallocation of resources toward riskier projects or from reaching for yield or higher leverage, particularly if the additional risk 
is concentrated in systemically important financial firms. As a corollary, policymakers might need to worry less about spurring reaching-for-yield behavior if unconventional policy simultaneously reduces financial institution risk by improving legacy asset values.

With this guidance in mind, the paper's results lead to three conclusions regarding the effects of unconventional policy on financial institutions. First, the expansionary policy of the winter of 2008-09 had an important component of financial rescue, particularly for life insurers. The subsequent designation of a large life insurer (Prudential) as a systemically important institution accentuates the value of helping life insurers' balance sheets to recover. Second, a low interest rate environment does pose challenges to money market funds and pension funds. Some of these funds will reach for yield, given the opportunity. Third, both life insurers and banks continued to benefit from expansionary monetary policy in 2013, and I find no evidence of money market funds or pension funds reaching for yield in 2012 or 2013. At least in the economic environment that prevailed at the end of 2013, there does not seem to be a trade-off between expansionary policy and the health or stability of the financial institutions studied.

The paper's results also relate to a literature on the role of financial institutions in transmitting monetary policy. One strand of this literature emphasizes the relationship between the stance of monetary policy and banks' cost of funds and hence their loan supply schedules (Bernanke and Blinder 1992; Gertler and Gilchrist 1994; Kashyap and Stein 2000). More recent work posits a risk taking or risk premia channel by which a reduction in the monetary policy rate causes financial institutions to increase their risk taking, resulting in lower risk premia and amplifying the magnitude of the interest rate cut (Adrian and Shin 2010; Borio and Zhu 2012; Hanson and Stein 2012). The evidence of some money market funds and pension funds increasing their risk taking in 2009-11 provides empirical support for the risk taking channel, albeit in the special environment of near-zero nominal interest rates. Finally, Markus Brunnermeier and Yuliy Sannikov (2011) construct a model where monetary easing works by recapitalizing financial institutions, similar to the legacy asset channel described above. The positive effects on life insurers during winter 2008-09 give support to this recapitalization view of monetary policy.

Section I of this paper characterizes the theoretical effects of unconventional monetary policy on financial institutions. Section II presents the event studies of life insurance companies and bank holding companies. Sections III and IV analyze the responses of money market funds and pension funds, respectively. Section V concludes. 


\section{Theoretical Channels}

The policy instruments of a sustained low federal funds rate, forward guidance, and large-scale asset purchases or quantitative easing (QE) affect the economy by lowering long-term real interest rates. It is useful to distinguish an expectations channel from a portfolio balance channel. Each of the three instruments may trigger the expectations channel by lowering the public's expectation of the path of policy rates. Through the expectations hypothesis of the term structure, long-term nominal interest rates then fall. Additionally, forward guidance and QE may generate an expectation of a lower policy rate after the zero lower bound no longer binds, causing consumption to boom in that future state and raising spending immediately through the Euler equation. The fall in nominal interest rates and the increase in spending generate a rise in expected inflation. Finally, lower long-term nominal interest rates and higher inflation together imply a decline in longterm real interest rates. The portfolio balance channel operates only with the policy instrument of QE. Here investors value certain types of securities beyond their risk-adjusted payoff structure (for example, satisfying regulatory requirements or due to habit or market segmentation). The central bank can then affect interest rates other than the short-term policy rate by changing the portfolio of assets private investors must hold in equilibrium.

I next discuss four channels through which low interest rates affect financial institutions. The concept of distance to default provides a useful organizing framework. The distance to default $\left(D D_{t}\right)$ of a firm is

$$
D D_{t}=\left[\frac{V_{A, t}-V_{A}^{*}}{V_{A, t}}\right] \frac{1}{\sigma_{A, t}},
$$

where $V_{A, t}$ denotes the present value of the firm's assets (including intangible assets), $V_{A}^{*}$ denotes the asset boundary at which the firm will default, and $\sigma_{A, t}$ denotes the standard deviation of the firm's $(\log )$ assets. The asset boundary $V_{A}^{*}$ depends in general on the size of the firm's liabilities and the strictness of debt holders in enforcing positive net worth covenants. The expression has its origins in the Merton (1974) model of credit risk, and today it underlies academic and industry measures such as Moody's KMV model.

$D D_{t}$ measures the distance between a firm's current assets and its default barrier in units of standard deviation. Higher $D D_{t}$ indicates a lower probability of default. In the language of the introduction, changes in $\sigma_{A, t}$ 
summarize the effect of monetary policy on financial institution risk taking, while financial sector stability depends on the distribution of $D D_{t}$.

\section{I.A. Real Spending}

Lowering long-term real interest rates stimulates riskless spending, through households' substituting intertemporally, firms' discounting future profits at a lower rate, and a positive wealth effect from a commitment to future expansionary policy. These effects form the textbook channel of monetary policy (Werning 2012).

Reducing the risk-free interest rate also stimulates spending on risky projects. Project risk comes from uncertainty about, inter alia, consumer taste shocks, future technology, future tax policy, and regulation. In corporate finance, investment decisions depend on whether the expected return from a project exceeds the project's hurdle rate. The hurdle rate depends on both the cost of capital and the project's riskiness. When the risk-free interest rate declines, newly viable projects have either lower expected returns or higher risk. If projects on the margin of funding mostly have higher risk, total project risk in the economy will rise. If, instead, the marginal projects have lower expected returns and lower variance than the average project, total risk will fall. A change in project risk maps into a change in $\sigma_{A, t}$ in equation 1.

A small model illustrates the channel. Consider a two-period economy consisting of a representative consumer, a producer, and a monetary authority. The producer passively provides output in exchange for money, at a price normalized to 1 . The consumer enters period 0 with real money balances $Y_{0}$ and may purchase output from the producer or make deposits at the monetary authority at a safe gross real interest rate $R^{f} .^{2}$ Purchased output can be consumed immediately or invested in a project with risky return. The space of projects indexed by expected return $\mu$ and variance $\sigma^{2}$ characterizes the investment opportunities. There are $K(\mu, \sigma)$ mutually independent projects with mean $\mu$ and variance $\sigma^{2}$, each of which can receive either one unit of investment or no investment. Importantly, investment projects do not have scalability_increasing investment by more than $K$ requires accepting

2. The model could easily accommodate demand-constrained producers as in a standard New Keynesian model. $R^{f}$ has the literal interpretation of interest paid on reserves at the monetary authority, with two caveats. First, $R^{f}$ is a real rather than nominal return. Implicitly, agents have perfect foresight over the path of inflation. Second, in this simple two-period economy, $R^{f}$ encompasses all of the policy instruments described above. 
either a lower mean return or higher project variance. Let $A(\mu, \sigma)=1$ if the project receives investment and 0 otherwise, where all (ex ante identical) projects with the same $(\mu, \sigma)$ either receive or do not receive funding. The consumer chooses allocations to maximize utility from consumption $C_{0}$ and $C_{1}$,

$$
U_{0}=u\left(C_{0}\right)+\beta E_{0}\left[u\left(C_{1}\right)\right]
$$

subject to the period budget constraints

$$
Y_{0}=C_{0}+A^{f}+A^{p}
$$

and

$$
C_{1}=R^{f} A^{f}+R^{p} A^{p}
$$

where $A^{f}$ denotes the allocation to the safe deposit, $A^{p}$ the portfolio of risky assets, and $R^{p}$ the (endogenous) return on the risky portfolio. $C_{0}$ and $A^{p}$ require purchased output and therefore constitute real spending. Deposits $A^{f}$ do not utilize real resources.

Online appendix $\mathrm{B}^{3}$ shows that with parametric assumptions on the utility function (CARA) and the distribution of returns on projects (independent normal), the consumer's problem simplifies to a mean variance trade-off where projects receive funding if their expected excess return $\mu-R^{f}$ exceeds a multiple $\gamma / 2$ of their variance, where $\gamma>0$ is the coefficient of absolute risk aversion. This gives rise to a mean-variance frontier, on and below which every asset receives funding. The frontier has slope $2 / \gamma$ in $\left(\mu, \sigma^{2}\right)$ space and has a right bound at the economy's maximum expected return $\mu_{H}$. If the consumer makes strictly positive riskless deposits, $A^{f}>0$, then $\left(R^{f}, 0\right)$ must lie on the frontier. Figure 1 illustrates the set of funded projects in $\left(\mu, \sigma^{2}\right)$ space.

Expansionary monetary policy - a decline in the risk-free rate $R^{f}-$ generates a parallel shift out of the mean-variance frontier. Immediately, total spending on risky assets $A^{p}$ increases. Moreover, spending on riskier projects rises, in the sense that at every mean return projects with higher variance now receive funding. However, the increased spending on risky projects does not necessarily imply an increase in the total riskiness of the economy, because spending on projects with low returns and low risk also rises. Whether the variance of the total investment portfolio $\left(\sigma^{p}\right)^{2}$ rises

3. Online appendixes for this volume may be found at the Brookings Papers website, www.brookings.edu/bpea, under "Past Editions." 
Figure 1. Set of Funded Projects

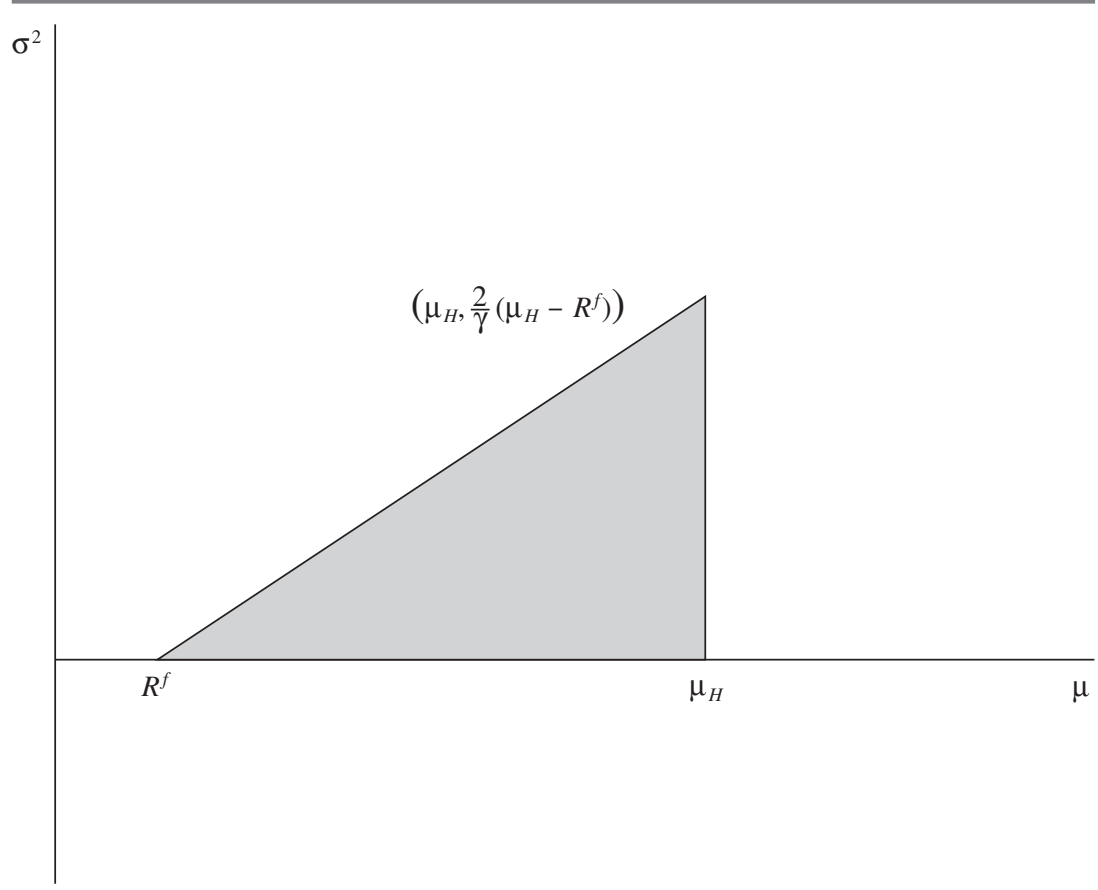

or falls depends on the relative densities of high-risk, high-return projects and low-risk, low-return projects on the margin of funding, that is, on the distribution of $K(\mu, \sigma){ }^{4}$

If the change in real spending does tilt toward riskier projects, the financial system will have exposure to the additional risk through its role in intermediating between savers and borrowers. Notably, this change in risk taking does not require any departure from the first-best allocation of resources. As a corollary, changes in the risk quantity or pricing of new lending cannot alone determine optimality. At least some increase in the asset risk of financial institutions may constitute an intended channel of unconventional monetary policy.

\section{I.B. Reaching for Yield}

Low interest rates may also spur risk taking by financial institutions beyond what the ultimate holders of the risk would prefer. Investment management

4. For example, if $K(\mu, \sigma)=1 \forall \mu, \sigma$, one can show that both $\mu^{p}$ and $\left(\sigma^{p}\right)^{2}$ unambiguously decline. Even so, risk in the financial system might still increase if not all institutions hold the same portfolio. 
poses a classic principle-agent problem, in which the incentives of managers may not align perfectly with the objectives of shareholders and debt holders (Jensen and Meckling 1976; Rajan 2005). Chairman Bernanke referenced these concerns in his May 2013 Congressional testimony:

The Committee is aware that a long period of low interest rates has costs and risks... [and] one that we take very seriously, is the possibility that very low interest rates, if maintained too long, could undermine financial stability. For example, investors or portfolio managers dissatisfied with low returns may reach for yield by taking on more credit risk, duration risk, or leverage. ${ }^{5}$

The definition of reaching for yield varies across authors. I use it to mean increases in risk taking for reasons other than the end-holder's risk preferences. In the language of the model in section I.A, reaching for yield is an increase in the slope of the funding frontier without a change in the risk aversion coefficient $\gamma$. The additional risk, corresponding to higher $\sigma_{A, t}$ in equation 1, may come from shifting investments into higher-risk asset classes (for example, equities instead of investment grade debt), choosing higher-yield investments within an asset class, or increasing leverage. The following sections give explicit examples of why some financial institutions might reach for yield (see also Stein 2013a).

\section{I.C. General Equilibrium Effects}

Low interest rates have general equilibrium effects on financial institutions because they boost aggregate demand. Higher real spending raises the profits of nonfinancial firms, and a decline in unemployment leads to lower loan delinquency and charge-off rates. Higher profits and lower default probabilities raise state-contingent payoffs and hence asset values. Asset values may rise further if the discount rate used to discount risky future profits falls, as for example consumption-based asset pricing models would predict.

Higher asset prices raise the value of legacy assets held by financial institutions, a phenomenon that Brunnermeier and Sannikov (2011) refer to as "stealth recapitalization." Increases in legacy asset prices correspond to an increase in $V_{A, t}$ in equation 1 . The resulting rise in net worth increases distance to default. If proximity to bankruptcy encourages risk-shifting behavior, the increase in net worth will also reduce the amount of risk taking by financial institutions, resulting in lower asset volatility $\sigma_{A, t}$ as well.

5. Testimony of Chairman Ben S. Bernanke before the Joint Economic Committee, U.S. Congress, Washington, D.C., May 22, 2013 (http://www.federalreserve.gov/newsevents/ testimony/bernanke20130522a.htm). 
Increased aggregate demand may also benefit financial firms if demand for financial products has a positive income elasticity. For example, life insurers' income from life insurance premiums tends to fall when the unemployment rate rises. ${ }^{6}$

\section{I.D. Leverage}

Finally, the corporate finance literature has highlighted reasons why low interest rates may affect leverage decisions apart from the motivation to reach for yield. The channel mostly concerns banks. A decline in the safe interest rate reduces the cost of holding required reserves or collateral. For banks facing binding collateral constraints or reserve requirements, the decline in the opportunity cost leads to larger total portfolios and higher leverage (Stein 2012; Dell' Ariccia, Laeven, and Marquez 2014; Drechsler, Savov, and Schnabl 2013). ${ }^{7}$ Brunnermeier and Sannikov (2014) describe a related phenomenon stemming from the low volatility environment induced by low interest rates. As low realized volatility feeds into banks' value-atrisk models, banks respond by increasing leverage. In the Merton model, leverage corresponds to the entire first term $\left[\frac{V_{A, t}-V_{A}^{*}}{V_{A, t}}\right]$.

\section{I.E. Summary}

Unconventional monetary policy affects the risk held by financial institutions in three ways: by changing the hurdle rate for risky projects, through general equilibrium effects on asset values and product demand, and by possibly causing some institutions to reach for yield or expand leverage. Project risk and reaching for yield affect $\sigma_{A, t}$ the forward standard deviation of asset returns. Raising the price of legacy assets increases $V_{A, t}$, while leverage affects the entire first term of equation 1.

I next turn to an empirical assessment of the effects of unconventional policy on four classes of financial institutions: life insurance companies,

6. Specifically, at an annual frequency the cyclical component (HP cycle divided by HP trend, smoothing parameter 6.25) of life insurance premiums and the cyclical component of the unemployment rate have a correlation coefficient of -0.56 over the period $1985-2012$, with a $p$ value against no correlation of 0.002 . The correlation remains negative and marginally significant, excluding the years 2008-12. Data on life insurance premiums come from the American Council of Life Insurers (2013).

7. The increase in leverage can exceed the first-best increase. In Stein (2012), a fire sale externality makes one bank's expanded leverage negatively affect the asset values of another bank in the event of a deleveraging shock. Because banks do not internalize the effect of their own leverage decision on the collateral constraints of other banks, the fire sale externality can lead to an increase in leverage beyond the social optimum. 
bank holding companies, money market funds, and pension funds. The analysis of life insurers and banks examines the total effect of unconventional policy on these institutions. For money market funds and pension funds, I narrow the focus to reaching for yield behavior and the effect on forward volatility $\sigma_{A, t}{ }^{8}$

\section{Life Insurance Companies and Bank Holding Companies}

I measure the effect of unconventional policy on life insurance companies and bank holding companies using event studies. Event studies permit one to identify the causal effect of a monetary policy surprise on asset prices. ${ }^{9}$ Identification requires (i) a window narrow enough that aggregate shocks other than the monetary policy shock do not affect the asset price during the window, and (ii) a window wide enough to allow markets to process the new information.

I compile a data set of CDS, bond, and equity prices of life insurers and bank holding companies as well as Treasury prices. Single-label CDS data come from Bloomberg generic quotes for contracts with a five-year tenor (contract horizon), written in U.S. dollars, and with a modified restructuring (MR) clause..$^{10}$ I obtain end-of-day quotes for Tokyo, London, and New York, each corresponding to the last trade before 5:15 p.m. local time. The bond price data come from the FINRA TRACE database, which contains transaction-level data for over-the-counter bond transactions collected by FINRA per the rule 6200 series. The equity data come from the TAQ database of tick-by-tick transactions from the consolidated tape of stocks traded on the NYSE. GovPx provides tick-by-tick indicative bid and ask prices on Treasury securities from five inter-dealer brokers. The life insurer sample contains an unbalanced panel of all life insurers in the top 30 by assets, excluding AIG, and with outstanding equity (13 firms), debt (11 firms), or CDS (4 firms) securities. The 13 life insurers in the equity sample together

8. For money market funds, absence of a capital buffer makes $\sigma_{A, t}$ a near-sufficient statistic for the likelihood of the money market version of default ("breaking the buck").

9. See Nakamura and Steinsson (2013) for the effect of conventional policy and Gagnon and others (2010) and Krishnamurthy and Vissing-Jorgensen (2011) for the effect of unconventional policy on interest rates. English, Van den Heuvel, and Zakrajsek (2012) and International Monetary Fund (2013, chapter 3) extend the methodology to the study of the effect on commercial bank stock prices, and Kiley (2013) and Gilchrist and Zakrajsek (2012) examine the effect on corporate borrowing rates and default risk, respectively.

10. Contracts with an MR clause give the protection buyer some recourse in the event of a credit event other than outright default. The five-year tenor and the MR clause characterize the most liquid contracts for the reference entities studied. 
held 45 percent of total life insurer assets at the end of 2012. The bank holding company sample contains an unbalanced panel of all bank holding companies with publicly traded equity (305 firms) or bonds (46 firms); it also contains the CDS spreads for eight of the largest bank holding companies.

Single label CDS spreads provide a market price tied to an institution's likelihood of default. When quoted in basis points, the CDS spread, or premium, gives the required annual payment for a contract that will pay $\$ 10,000$ if the reference institution triggers a default clause during the contract horizon. Holding the price of risk fixed, an increase in the spread therefore indicates a decline in the distance to default and an increase in the default probability of the reference entity. The spread between the bond yield and the Treasury yield measures the bond risk premium. The equity response gives the stock market's perception of the effect of the surprise on the institution's future net income, suitably discounted. The liquidity in equity markets permits the narrowest windows of the assets studied and the inclusion of the largest number of firms.

For all three assets, the response reflects the combination of the effects described in section I, as well as any change in the economy-wide price of risk induced by the monetary policy action. That is, I do not separate movements in the bond or CDS premium into the change in default probability (the quantity of risk) and the excess premium (the price of risk) (see Gilchrist and Zakrajsek 2012, for further discussion). Furthermore, market beliefs about the effects of unconventional policy may diverge from the true effects. In this regard, I present some evidence of actual events unfolding in a manner consistent with the market expectation, and find that markets did not substantially change their views in 2013 even with the addition of four years of data on the effects of unconventional policy.

Table 1 lists the monetary policy surprise dates, grouped into four policy programs. QE1 consists of the initial round of asset purchases announced in late 2008 and lasting through 2009. QE2 corresponds to purchases announced in November 2010. QE3 consists of purchases begun in September 2012 and still ongoing as of March 2014. FG contains dates related to forward guidance. Through 2012, the dates form a subset of the announcement dates listed by the International Monetary Fund (2013). With the exception of the initial announcement on November 25, 2008, which occurred before normal trading hours, I keep all dates used by Arvind Krishnamurthy and Annette Vissing-Jorgensen (2011). However, because my interest lies in identifying the conditional response of financial institution asset prices to monetary policy surprises, I exclude some other announcements that do not move the 
Table 1. Unconventional Monetary Policy Announcement Dates and Effect on 5-Year Treasury Notes, December 2008 to September 2013

\begin{tabular}{|c|c|c|c|c|}
\hline Episode & Date & Time & Event & $\begin{array}{c}\text { Effect on 5-year } \\
\text { Treasury note } \\
\text { (basis points) }\end{array}$ \\
\hline QE1 & December 1, 2008 & 1:45 p.m. & Bernanke speech & -9.2 \\
\hline QE1 & December 16, 2008 & 2:21 p.m. & FOMC statement & -16.8 \\
\hline QE1 & January 28, 2009 & 2:15 p.m. & FOMC statement & 3.1 \\
\hline QE1 & March 18, 2009 & 2:17 p.m. & FOMC statement & -22.8 \\
\hline QE1 & September 23, 2009 & 2:16 p.m. & FOMC statement & -8.9 \\
\hline QE2 & August 10, 2010 & 2:14 p.m. & FOMC statement & -5.8 \\
\hline QE2 & September 21, 2010 & 2:14 p.m. & FOMC statement & -1.8 \\
\hline FG & August 9, 2011 & 2:18 p.m. & FOMC statement & -14.4 \\
\hline FG & January 25, 2012 & 12:28 p.m. & FOMC statement & -6.3 \\
\hline QE3 & September 13, 2012 & 12:31 p.m. & FOMC statement & 6.4 \\
\hline QE3 & May 22, 2013 & 10:30 a.m. & Bernanke testimony & 6.6 \\
\hline QE3 & June 19, 2013 & 2:00 p.m. & FOMC statement & 7.8 \\
\hline QE3 & July 10, 2013 & 4:45 p.m. & Bernanke speech & -7.3 \\
\hline QE3 & September 18, 2013 & 2:00 p.m. & FOMC speech & -14.0 \\
\hline
\end{tabular}

a. Change in the yield to maturity of the on-the-run 5-year Treasury note from the 5-minute window ending 2 minutes before the announcement to the 5-minute window beginning 18 minutes after the announcement. The yield to maturity is based on the mean of the indicative bid and ask prices in each window.

5-year Treasury. ${ }^{11}$ Each of the included announcements from 2013 had an identifiable Federal Reserve communication and a discrete change in the Treasury yield at the time of the announcement.

For equity and bond prices, I use tick-by-tick data to construct the difference in the 5-minute average trading price from 7 to 2 minutes before the monetary policy announcement to 18 to 23 minutes after. The narrow intraday window virtually ensures that other aggregate shocks do not contaminate the results (Nakamura and Steinsson 2013; Kiley 2013). Furthermore, both the TRACE bond data and the TAQ equity data contain prices from actual trades, and the constructed windows contain only securities with valid

11. For example, the International Monetary Fund (2013) list includes November 3, 2010, when the FOMC announced a new round of asset purchases. Market participants widely expected this announcement, and the Treasury barely reacted on impact. As a result, I include two dates, August 10 and September 21, 2010, when FOMC statements raised expectations of future purchases and Treasury prices rose, but exclude the November 3 announcement itself. As in Krishnamurthy and Vissing-Jorgensen (2011), my focus on conditional responses to monetary surprise shocks implies a loss of power but no bias from omitting valid policy surprises. 
transactions both before and after the announcement. This alleviates the concern that market illiquidity could bias price changes toward zero. For CDS spreads, I use data from the market closings in Tokyo (3:15 a.m. Eastern), London (12:15 p.m. Eastern), and New York (5:15 p.m. Eastern) to construct quasi-intra-day windows, covering the shortest possible amount of time surrounding each announcement. While using the CDS data raises more concern about incorporating information other than the monetary policy surprise, the quasi-intra-day refinement substantially improves on using only daily frequency. ${ }^{12}$

I use Treasury prices to validate the second identification assumption. Online appendix figure C.1 shows minute-by-minute yields of the on-the-run 5 -year Treasury note on each date. The dashed lines define the period from 2 minutes before to 18 minutes after each announcement. Treasuries adjust to the news almost instantaneously, with the narrow window being sufficient to capture nearly all of the movement. ${ }^{13}$ The window does assume market participants interpret the effect of an announcement on individual bond or equity prices as quickly as they do the effect on Treasuries. Section II.C conducts robustness exercises.

\section{II.A. Life Insurer Results}

Life insurers' liabilities in the United States consist of roughly $\$ 4.5$ trillion in life insurance policies and annuities (American Council of Life Insurers 2013). Life insurers divide their asset holdings between a general account, backing essentially all of their life insurance policies as well as fixed-rate annuities, and a separate account, backing pass-through products such as variable-rate annuities and pension products. State laws regulate the asset allocation of the general account but not the allocation of the separate account.

Both annuities and life insurance contracts often have longer durations than asset holdings, causing duration mismatch on insurers' balance sheets. When interest rates fall, life insurers face a compressed or even negative

12. For example, the Markit end-of-day spreads for March 17, 2009, and March 18, 2009, indicate an increase of 51 basis points in the value-weighted mean life insurer spread. To preview a result to come, using the change between the London and New York close instead gives a decline of 25 basis points.

13. The on-the-run security is the mostly recently issued of a given tenor and generally has the greatest liquidity. In some cases the surprise announcement came in the form of an FOMC statement, which was later followed by a chairman's press conference. Although Treasury prices also respond to news from the press conference, I limit the window to include only effects from the statement itself. 
interest spread as they roll over their assets at the lower rates. While the long-term liability structure insulates them from the threat of runs, a compressed spread reduces operating profits. This has led some industry analysts to postulate that low interest rates have a negative effect on life insurers, especially if they persist for a long time (Moody's Investors Services 2012; McKinsey Global Institute 2013). Life insurers can try to offset the lower interest rates by reaching for yield. The added risk ultimately passes through to policyholders, shareholders, and the state guarantee funds backing their policies in the event of bankruptcy. ${ }^{14}$

On the other hand, life insurers hold roughly one-quarter of their general account assets in mortgage-backed securities or directly held mortgages, and nearly half in corporate securities. These assets lost value during the 2008-09 crisis, rendering some life insurers nearly insolvent. Also, before the crisis many life insurers had sold variable annuities with minimum return guarantees, on which they would need to make good if the stock market did not recover sufficiently. As a result, the positive general equilibrium effects of Federal Reserve policy on asset prices may have benefited life insurers' equity values and reduced the likelihood of their insolvency.

Before reviewing the event study results, it will be helpful to view the broader time series of CDS spreads, which are the most direct measure of riskiness. Figure 2 plots the CDS spreads for the six insurance companies that had large life insurance components and publicly traded CDS. ${ }^{15}$ These time series cannot establish the causal effect of monetary policy, because they do not control for the many other policy and market events taking place during the period. However, they do provide context for the event studies as well as helping to assess whether the post-2009 environment cum unconventional monetary policy has resulted in an unusual concentration of risk.

As noted, insurance companies faced significant financial challenges during the 2008-09 crisis. A contemporary account put their estimated losses from assets related to the subprime crisis at greater than $\$ 180$ billion (Harrington and Frye 2009), contributing to a series of downgrades by rating agencies. Ralph Koijen and Motohiro Yogo (2013) report that many

14. For example, Becker and Ivashina (forthcoming) find evidence of life insurers reaching for yield before the crisis in the sense of choosing riskier fixed-income securities within regulatory asset classes. However, they also find the phenomenon diminished following the financial crisis.

15. These data come from Markit end-of-day quotes. The Bloomberg generic quotes used to construct the quasi-intra-day windows lack data for Aflac (ticker: AFL) and Hartford Financial Services (ticker: HIG). 
Figure 2. Insurance Company CDS Spreads, 2008-13

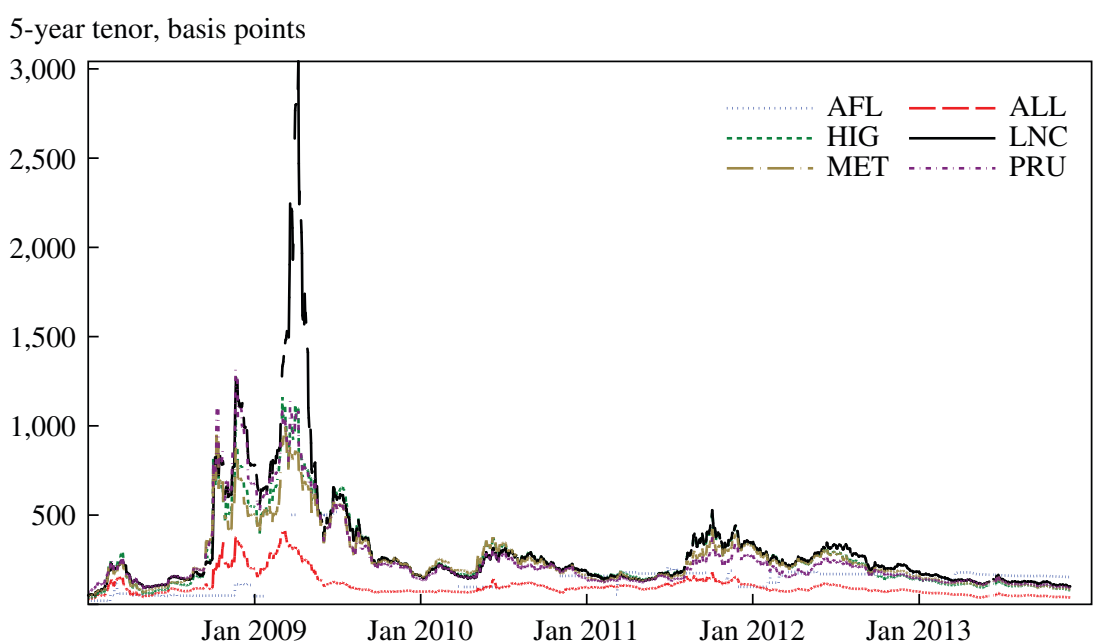

life insurers sold policies at deep discounts during the period to exploit an accounting loophole and avoid further downgrades. The spikes in the CDS spreads in early 2009 reflect this distress. The annual CDS premium required for a payoff of $\$ 10$ million in the event of a default by Lincoln Financial (ticker: LNC) reached the equivalent of $\$ 3$ million per year, while CDS premiums on MetLife (ticker: MET), Prudential (ticker: PRU), and Hartford Financial (ticker: HIG) all went as high as $\$ 1$ million per year. ${ }^{16}$ Spreads began to decline in March and April of 2009, roughly coinciding with the stabilization of financial markets generally and the beginning of the recovery in asset prices. The timing thus appears consistent with general equilibrium effects of Federal Reserve policy during the winter of 2008-09 benefiting life insurers. As of the end of 2013, CDS spreads have returned to historically low levels.

Turning to the event studies, figures 3 to 5 report the responses of life insurers' CDS spreads, bond yields, and equity prices to the monetary

16. Because premium payments cease following a default event, especially distressed entities trade with an upfront payment along with fixed coupons. For example, on April 6, 2009 , purchasing a 5-year contract for $\$ 10$ million of protection against Lincoln Financial required an upfront payment of $\$ 4.85$ million and annual coupon payments of $\$ 500,000$ thereafter. The spreads reported in figure 2 and the Bloomberg generic quotes reported below use the ISDA CDS standard model to amortize the upfront payment and report as if the only required payment were annual premiums. 
Change in on-the-run 5-year Treasury, basis points ${ }^{\mathrm{b}}$

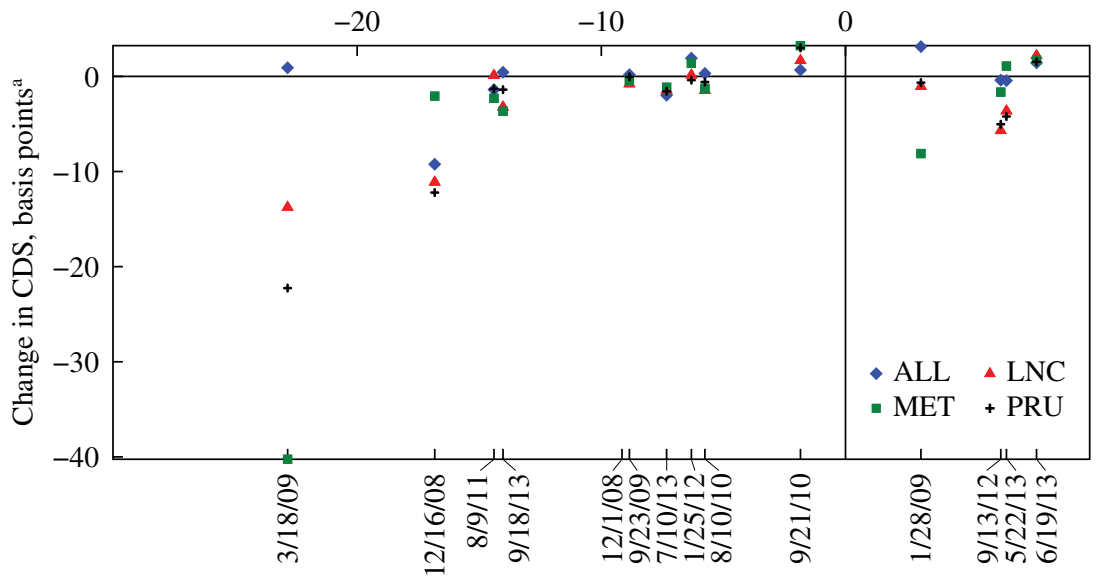

Announcement date

a. The change in CDS is the change in the 5-year spread, Tokyo close to London close (announcement before 12:15 p.m.) or London close to New York close (announcement after 12:15 p.m.), on the announcement date.

b. The change in the on-the-run 5-year Treasury is the change in the yield to maturity from 2 minutes before to 18 minutes after the announcement.

Figure 4. Insurance Company Bond Price Response to Unconventional Monetary Policy Surprises, 2008-13

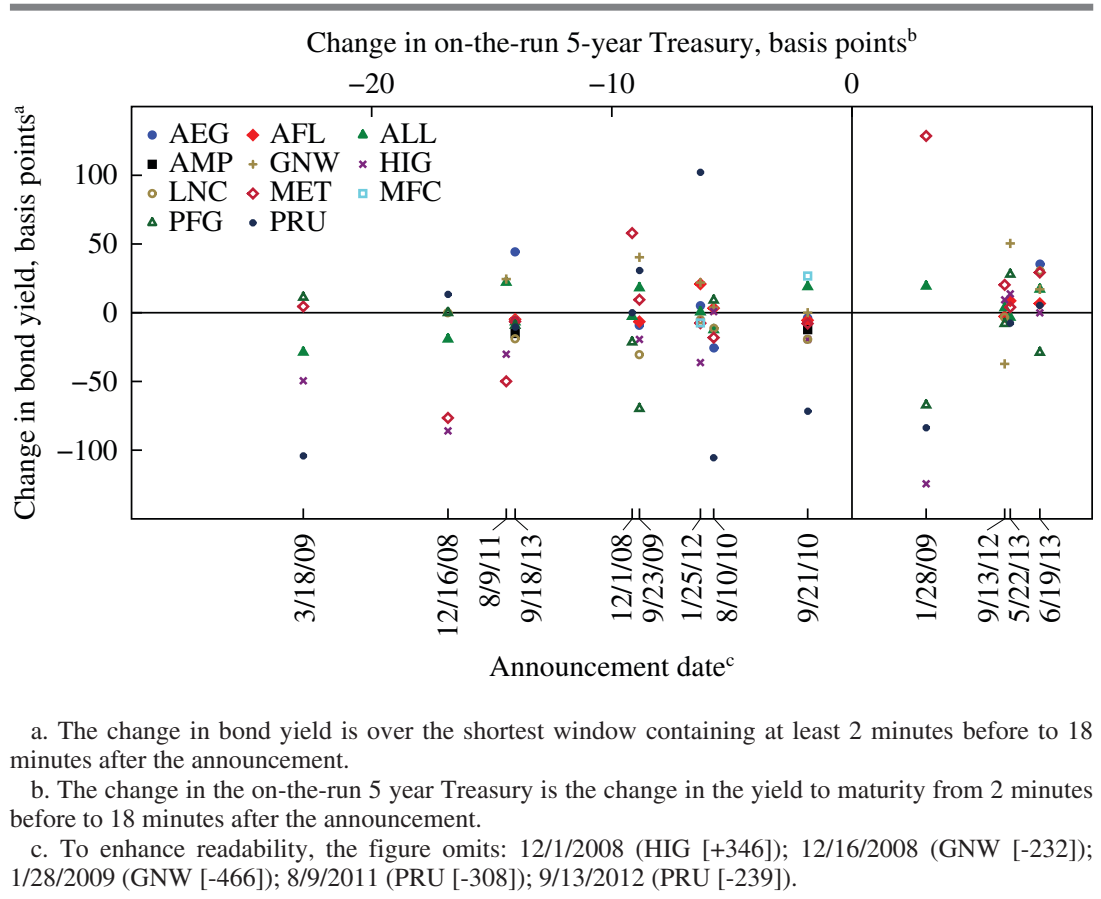


Figure 5. Insurance Company Stock Price Response to Unconventional Monetary Policy Surprises, 2008-13

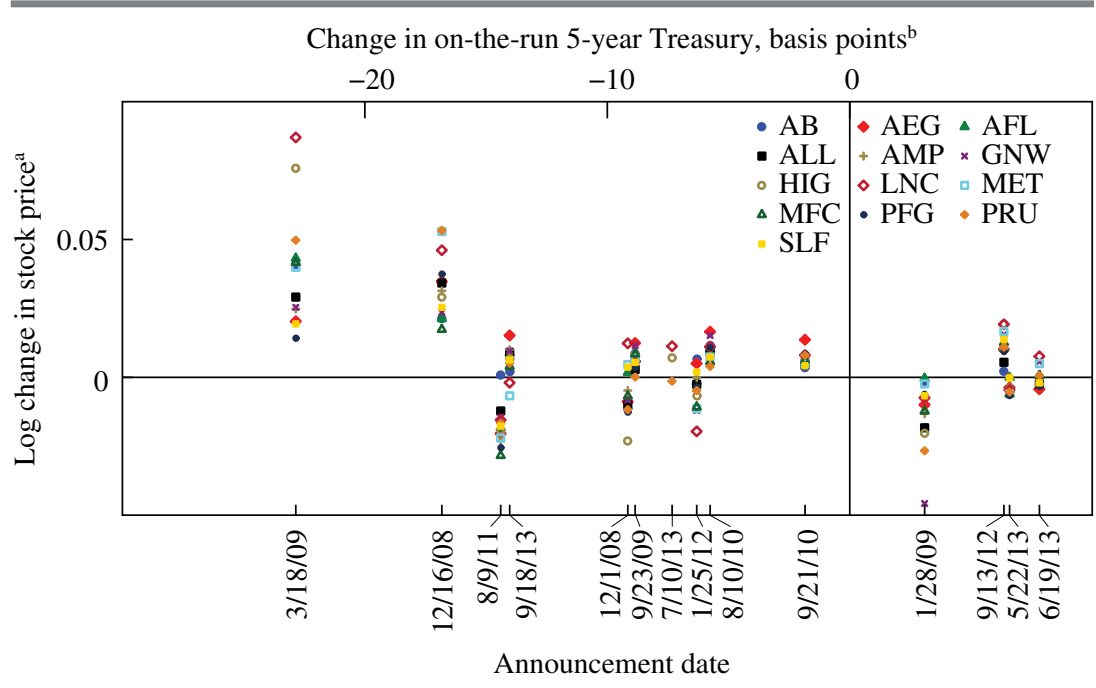

a. The log change in stock price is from 2 minutes before to 18 minutes after the announcement.

b. The change in the on-the-run 5-year Treasury is the change in the yield to maturity from 2 minutes before to 18 minutes after the announcement.

policy surprises. Each figure shows a scatterplot of the asset price change and the change in the 5-year Treasury, with the announcement date labeled on the lower horizontal axis. Table 2 reports the value-weighted mean for each announcement date. I use the sample average market capitalization as the weight for all three asset categories and construct significance thresholds from the larger of the conventional or robust standard error in a firm-level regression of the change in the asset price on a constant on each date. ${ }^{17}$ Shaded rows in the table indicate contractionary surprises, defined as a positive response of the 5-year Treasury yield during the announcement window. The table also reports the log change in the on-the-run North American

17. Some of the entries in table 2 have very few observations, in which case robust standard errors can have large upward bias (Angrist and Pischke 2009). Unlike some previous studies, I do not use movements on non-event days in constructing the standard errors. Under the identifying assumption that no other aggregate shocks occur during the event window, the standard errors used here inform whether the monetary policy shock has a statistically significant systematic effect on the asset prices studied. The results in both tables 2 and 3 change little whether one uses an unweighted mean or median as the measure of central tendency. 


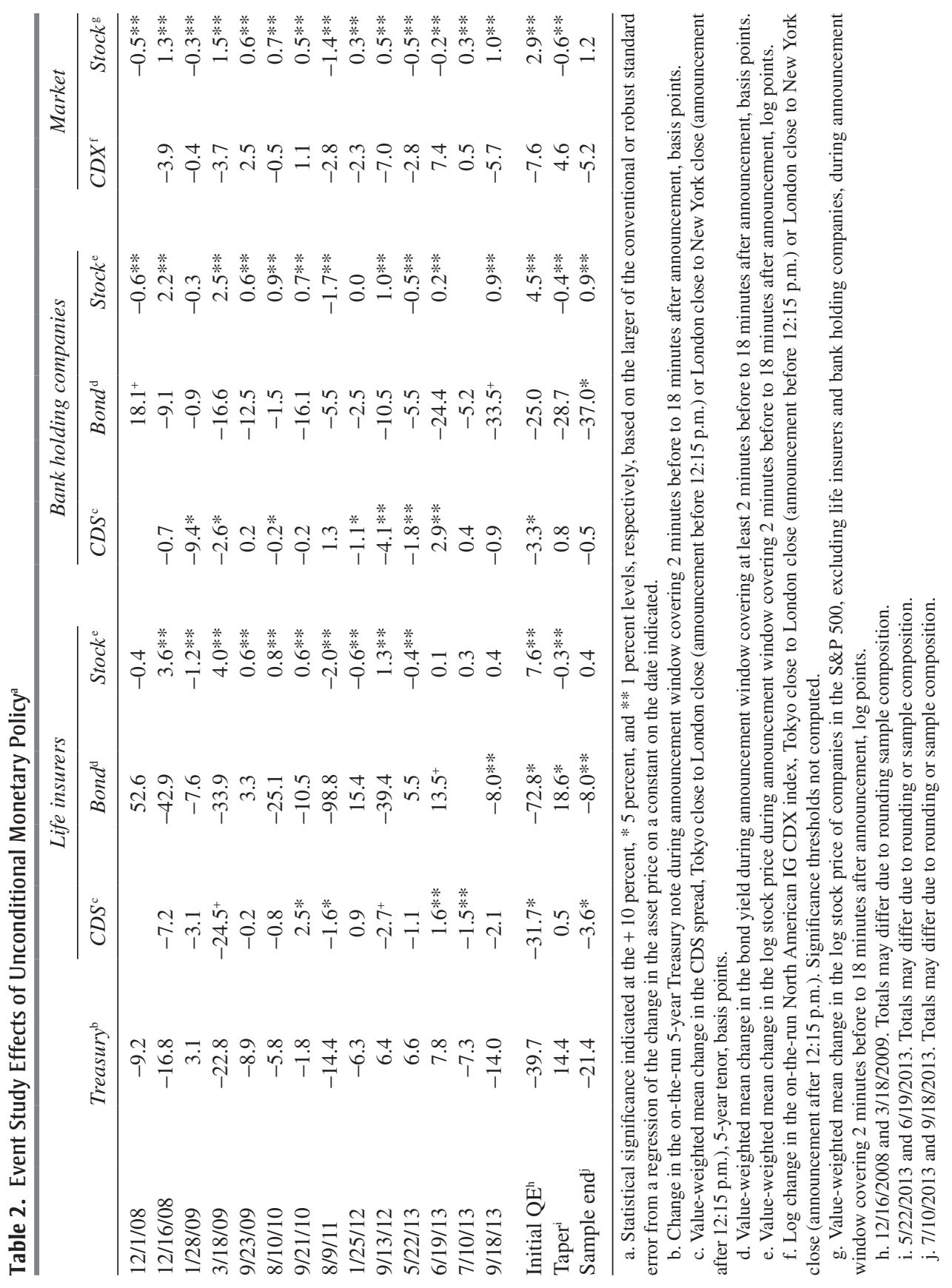


IG CDX and the value-weighted mean stock price change of all companies in the S\&P 500, excluding banks and life insurers. ${ }^{18}$

The comparison with nonfinancial firms helps qualitatively in distinguishing effects stemming from changes in the economy-wide price of risk from effects specific to the life insurance sector.

Consistent with strong general equilibrium effects, the introduction of near-zero interest rates and quantitative easing in the winter of 2008-09 had a clear, beneficial impact on life insurers. Using the response of the 5 -year Treasury yield as a guide, the two most important announcements occurred on December 16, 2008, when the FOMC announced a 75-basispoint reduction in the federal funds rate to a new target of $0-25$ basis points, and on March 18, 2009, when it announced a balance-sheet expansion of up to $\$ 1.15$ trillion. Summing over the changes in the two announcement windows gives a cumulative impact of 40 basis points on the 5-year Treasury. As illustrated in figure 5, every life insurer in the sample experienced an increase in its stock price during each announcement window, with a combined value-weighted change of 7.6 percent. In fact, equity prices of life insurers benefited far more from the announcements than did the average bank or the S\&P 500 excluding finance and insurance. The cost of insuring against default and bond yields also fell. The value-weighted 5 -year CDS spread fell 32 basis points over both announcements. The bond yield fell a total of 73 basis points, suggesting a decline in the risk premium. ${ }^{19}$

The general equilibrium effects on life insurers' legacy assets appear to have unfolded in line with the market's expectations. For example, MetLife's 2010 annual report opens its discussion of financial condition and result of operations by stating: "As the U.S. and global financial markets continue to recover, we have experienced a significant improvement in net investment income and favorable changes in net investment and net derivative gains" (MetLife, Inc. 2010, p. 6). The report goes on to attribute the investment gain to a "decrease in impairments and a decrease in the provision for credit losses on mortgage loans." The improvement in legacy assets accounted

18. The North American IG CDX, published by Markit, follows 125 North American single-label investment grade entities, chosen based on liquidity. The index "rolls" every 6 months, meaning on March 20 and September 20 of each year Markit launches a new index tracking CDS with a maturity date 5 years hence. The on-the-run CDX is the most recently launched index and the most liquid.

19. The maturity of bonds in the sample may differ from the 5-year maturity of Treasuries. On a value-weighted basis, the median remaining time to maturity of life insurer bonds in the sample is 5.8 years. 
Table 3. Value-Weighted Mean Price Response (Regressions) ${ }^{\mathrm{a}}$

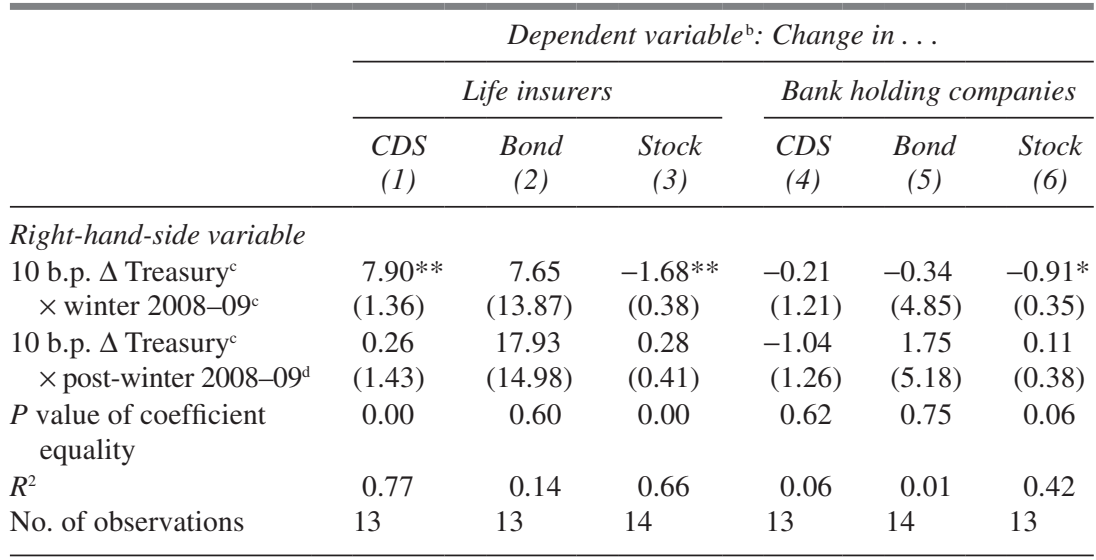

a. Statistical significance indicated at the +10 percent, $* 5$ percent, and $* * 1$ percent levels, respectively.

b. The dependent variable is the value-weighted mean change in the log stock price during announcement window covering 2 minutes before to 18 minutes after announcement, in log points, the value-weighted mean change in the CDS spread, Tokyo close to London close (announcement before 12:15 p.m.) or London close to New York close (announcement after 12:15 p.m.), 5-year tenor, in basis points, or the value-weighted mean change in the log bond price during announcement window covering at least two minutes before to 18 minutes after announcement, in log points, as indicated by the table header.

c. The variable 10 b.p. $\Delta$ Treasury is the change in the yield to maturity of the on-the-run 5-year Treasury from 2 minutes before to 18 minutes after the announcement, in 10-basis-point increments.

d. Winter 2008-09 includes all announcements in December 2008-March 2009.

for fully half of the increase in pretax operating income that MetLife experienced in 2010.

Subsequent announcements concerning unconventional policy had a more muted effect on life insurers. To help quantify the difference, the first three columns of table 3 report regressions of the value-weighted mean asset price response on the change in the 5-year Treasury, allowing for separate slope coefficients during winter 2008-09 and thereafter. The coefficients are signed such that a contractionary surprise corresponds to a positive realization of the right-hand side variable. As foreshadowed by the previous discussion, during winter 2008-09 a 10-basis-point expansionary surprise results in an 8-basis-point decline in both the CDS and the bond yields and a stock price increase of $1.7 \mathrm{log}$ points; both the CDS change and the stock price change are highly statistically significant. In contrast, the CDS and stock price coefficients for announcements after winter 2008-09 fall to essentially zero, and none of the asset prices exhibits a response statistically distinguishable from zero. To be sure, these regressions have only a handful of observations, and it is possible that market participants had greater difficulty interpreting later announcements during the narrow 
windows. ${ }^{20}$ Indeed, table 2 shows that many later individual announcements still had significant, if small, effects.

The announcement surprises in 2013 merit special mention. If market participants continually update their beliefs regarding how unconventional policy affects financial institutions, these dates should reflect the maturation of that process and hence contain more precise signals of the actual effect of the policies. In addition, during the spring of 2013 financial market expectations shifted toward an earlier taper of the Federal Reserve's most recent round of asset purchases than previously thought. The response of life insurers' asset prices to the contractionary policy surprises contained in Chairman Bernanke's congressional testimony in May 2013 and in the FOMC statement in June therefore provide information on the symmetry of the market's response.

Beginning with the taper surprises, the Treasury yield rose a combined 14.4 basis points during the two announcement windows. ${ }^{21}$ CDS spreads rose a statistically insignificant 0.5 basis point over the two dates, while bond yields rose a statistically significant 19 basis points and stock prices fell $0.3 \log$ point.

From the summer of 2013 I identify two expansionary policy surprises: a speech by Chairman Bernanke at the National Bureau of Economic Research and the September FOMC statement. Summing over the two events gives a decline in the 5-year Treasury of 21 basis points. The value-weighted mean CDS spread of life insurers declined on both dates. Of the 10 life insurers with bond transactions surrounding the September FOMC statement, nine experienced a decline in their yield, with a value-weighted mean decline of 8 basis points. ${ }^{22}$ The mean stock price rose on both dates. Expansionary policy continued to benefit life insurers in 2013.

To summarize, the event studies appear consistent with general equilibrium effects strong enough to generate a positive effect of unconventional

20. The "post" period includes two dates when the immediate response of the S\&P 500 differed from that of the 5-year Treasury yield. The first occurred on August 9, 2011, when the FOMC introduced calendar-based forward guidance. While Treasury yields fell immediately, the S\&P 500 fell initially before reversing and ending the day higher. The opposite occurred on September 13, 2012, with the introduction of a new round of QE. While the S\&P 500 rose immediately, Treasury yields also rose during the announcement window only to reverse the increase by the end of the day.

21. The 5 -year Treasury constant maturity yield rose by 95 basis points between May 1 and July 5, 2013. However, much of the movement came in response to stronger than expected economic data releases rather than to policy announcements. For example, the yield rose 21 basis points on July 5 following the release of the June employment report by the Bureau of Labor Statistics on that date.

22. I do not have bond yield observations for the NBER speech, because the speech took place after normal trading hours. 
monetary policy on life insurers. Many life insurers faced solvency concerns in early 2009, and the expansionary policy in the winter of 2008-09 appears to have had a substantial beneficial effect. This conclusion bears resemblance to previous work finding that lower-grade corporate bond prices reacted positively to the initial round of QE due to a decline in default risk (Krishnamurthy and Vissing-Jorgensen 2011), and that unconventional policy lowered downside tail risk in a broad class of asset prices (Hattori, Schrimpf, and Sushko 2013; Roache and Rousset 2013). Policy announcements subsequent to the 2008-09 period had smaller or neutral effects. However, even in late 2013 market participants continued to view expansionary monetary policy as beneficial to life insurers.

\section{II.B. Bank Holding Company Results}

The regulated banking sector remains at the core of the financial system in the United States. It also contains nearly all of the U.S. institutions designated as systemically important financial institutions. Bank holding companies stood to benefit from the general equilibrium effects of unconventional monetary policy on loan repayment and recovery rates as well as on the price of legacy securities on their balance sheets. As discussed earlier, a decline in the safe interest rate may also lead to higher leverage.

Figure 6 plots CDS spreads for the bank holding companies. Spreads rose sharply during the crisis, and they rose again in late 2011 amid concerns over the U.S. debt ceiling and sovereign defaults in Europe. As with life insurers, for bank holding companies spreads had returned to their pre-crisis levels by the end of 2013 .

Figures 7 to 9 present scatterplots of the event study results for the bank holding companies. They show that these companies also benefited from the introduction of unconventional monetary policy. Summing the effects over the announcements made on December 16, 2008, and March 18, 2009, seven of the eight banks in the CDS sample (all except Citigroup [ticker: C]) experienced a decline in their CDS spread. ${ }^{23}$ The value-weighted stock price increase of $4.5 \log$ points exceeded the increase of the average nonfinancial firm in the S\&P 500. The average bond yield fell 25 basis points.

23. This result contrasts somewhat with the small effects on banks' CDS found in Gilchrist and Zakrajsek (2013). The quasi-intra-day windows may explain the difference. Using the quasi-intra-day spread, table 2 shows a statistically significant decline of 3.3 basis points in response to the announcements on December 16, 2008, and March 18, 2009. Using the endof-day spreads reported by Markit instead gives a statistically significant increase of 5.3 basis points on the two announcement days. 
Figure 6. Bank CDS Spreads, 2008-13

5-year tenor, basis points

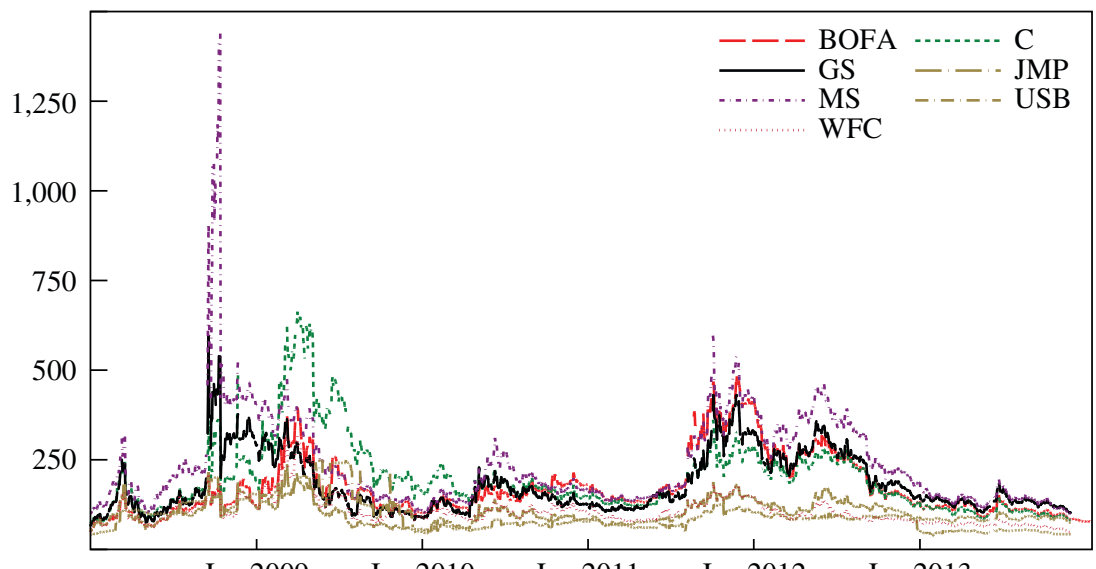

Jan $2009 \quad$ Jan $2010 \quad$ Jan $2011 \quad$ Jan $2012 \quad$ Jan 2013

Figure 7. Bank CDS Price Response to Unconventional Monetary Policy Surprises, 2008-13

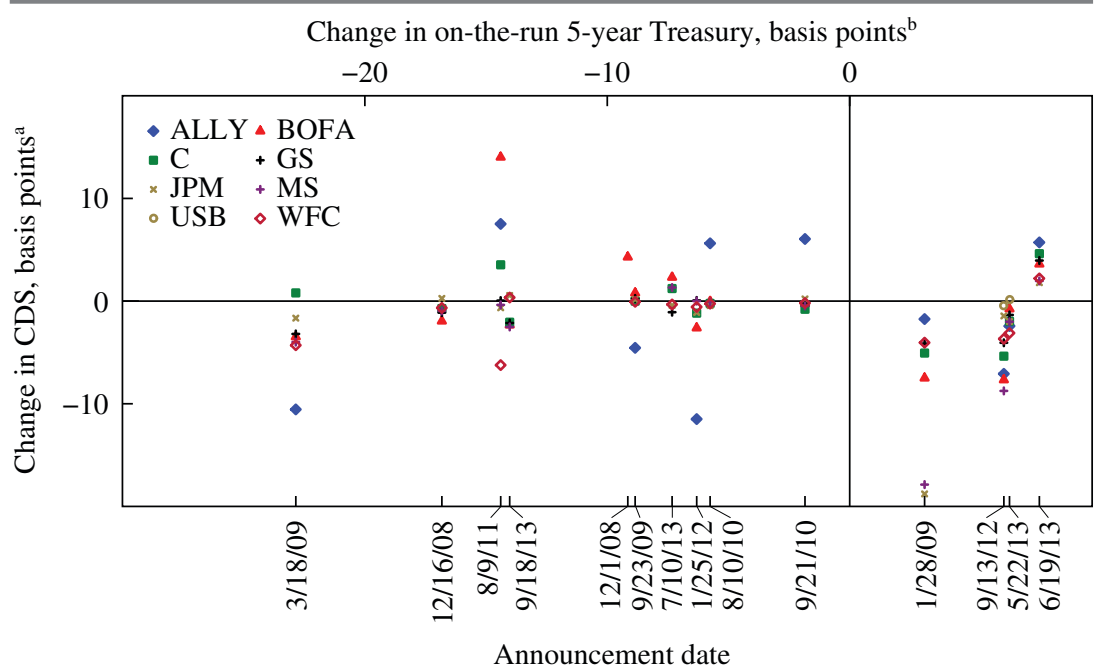

a. The change in CDS is the change in the 5-year spread, Tokyo close to London close (announcement before 12:15 p.m.) or London close to New York close (announcement after 12:15 p.m.), on the announcement date.

b. The change in the on-the-run 5-year Treasury is the change in the yield to maturity from 2 minutes before to 18 minutes after the announcement. 
Figure 8. Bank Bond Price Response to Unconventional Monetary Policy Surprises, 2008-13

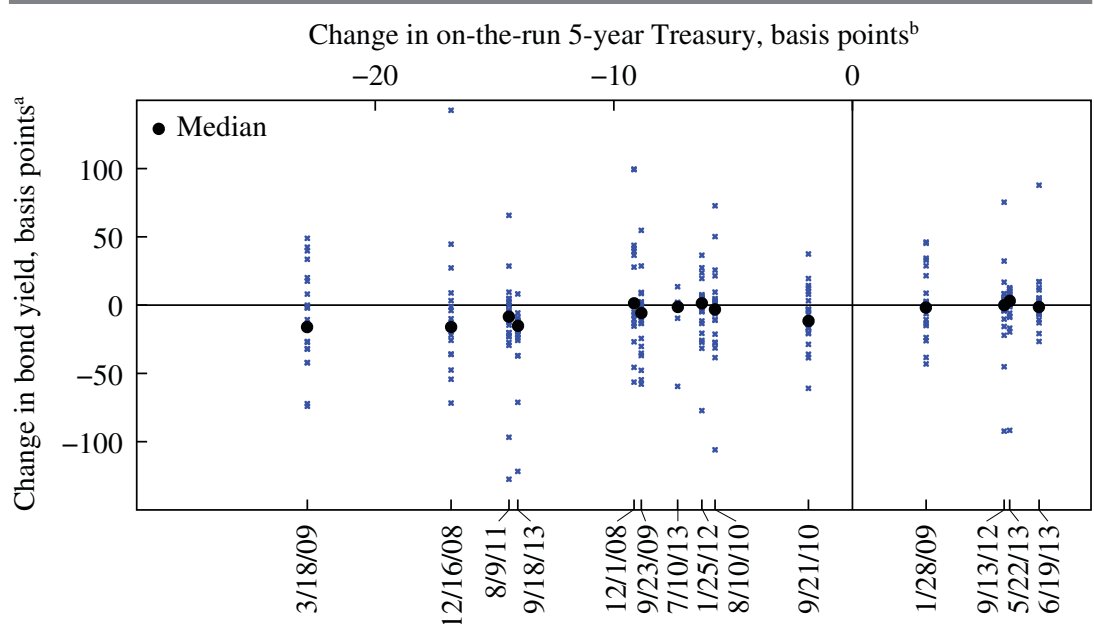

Announcement date

a. The change in bond yield is over the shortest window containing at least 2 minutes before to 18 minutes after the announcement.

b. The change in the on-the-run 5-year Treasury is the change in the yield to maturity from 2 minutes before to 18 minutes after the announcement.

c. To enhance readability, the figure omits: 12/1/2008 (CIT[+168]); 12/16/2008 (CIT[-370], BPOP[+688]); 1/28/2009 (CIT[-279], COF[-210]); 3/18/2009 (CIT[-576], COF[-300]); 9/21/2010 (BK[-326]); 5/22/2013 (ASBC[+307]); and 6/19/2013 (BAC[-203], TRV[+171]).

Figure 9. Bank Stock Price Response to Unconventional Monetary Policy Surprises, 2008-13

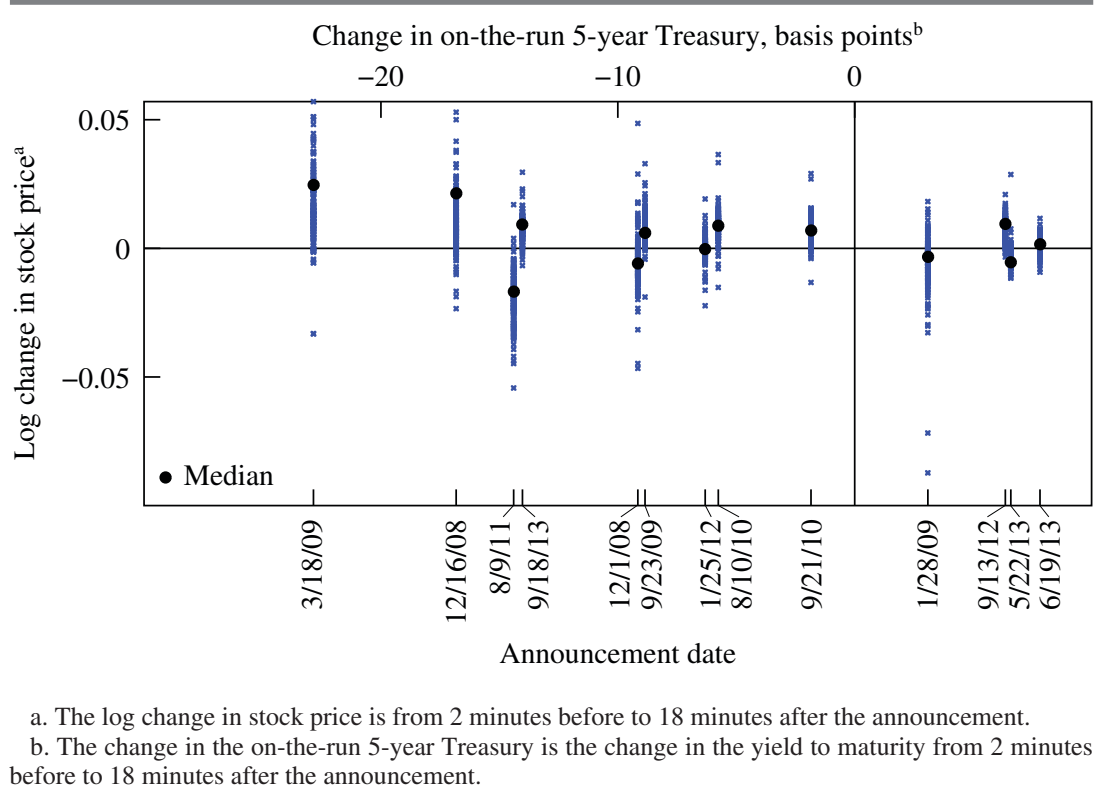


Once again, subsequent announcements had smaller effects on banks. As with life insurers, the sign of the response remains unchanged even in 2013. Unconventional monetary policy does not appear to raise concerns about the health or riskiness of regulated banks.

\section{II.C. Window Length Robustness}

The main analysis uses 30-minute windows to measure the response of equity and bond prices to unconventional monetary policy announcements. As stated above, a short window helps to ensure that other aggregate shocks do not contaminate the analysis. However, using the short window also assumes markets can rapidly process the effects of the monetary policy announcements on diverse institutions.

Table 4 tests whether the positive responses of life insurers and banks to expansionary surprises, and the relatively large response of life insurers to QE1, survive a longer window length. The table reports loadings of the stock prices of life insurers and banks on an index of nonfinancial firms following announcements. Why examine the loading on nonfinancial firms? From online appendix figure C.1, Treasury prices incorporate the monetary policy surprises extremely rapidly. The concern of a short window thus applies to whether stock prices react as quickly as Treasury prices, and in particular whether it takes additional time to differentiate the effects on certain sectors, such as life insurers or banks. Of course, using a longer window amplifies the concern that other news shocks might contaminate the results. Conditioning on the stock prices of nonfinancial firms provides one way of controlling for other aggregate shocks as the window length increases. It also gives a direct metric of whether equities of life insurers and banks react in the same direction as the broader market's reaction and whether the response of life insurers exceeds that of the broader market.

To construct the loadings, I generate minute-by-minute equity indexes of the value-weighted life insurance, banking, and nonfinancial sectors. The samples mirror those used previously; in particular, the nonfinancial sector contains all firms in the S\&P 500 minus those in insurance or banking. I then compute the log change in each index over non-overlapping 5-minute periods, beginning with the 5-minute period ending at the time of the announcement. The sample continues on each date for the shorter of 2 hours or until the end of the trading day at 4 p.m. Eastern. ${ }^{24}$ Finally, I report regressions of the log change in the life insurer or bank index on the

24. The sample excludes the July 10, 2013, announcement, which occurred after 4 p.m. For nine of the 13 other announcements, the 4 p.m. deadline binds. 
Table 4. Loadings on Nonfinancial Firms Following Monetary Policy Announcements (Regressions) ${ }^{\mathrm{a}}$

\begin{tabular}{|c|c|c|c|c|}
\hline \multirow[b]{3}{*}{ Explanatory variables } & \multicolumn{4}{|c|}{$\begin{array}{c}\text { Dependent variable: log change } \\
\text { in stock price index of } . .\end{array}$} \\
\hline & \multicolumn{2}{|c|}{ Life insurers } & \multicolumn{2}{|c|}{ Banks } \\
\hline & (1) & (2) & (3) & (4) \\
\hline$\Delta \log ($ nonfinancial firms $) \times \mathrm{QE} 1$ & $\begin{array}{l}1.96 * * \\
(0.27)\end{array}$ & $\begin{array}{l}1.86^{* *} \\
(0.20)\end{array}$ & $\begin{array}{l}1.07 * * \\
(0.066)\end{array}$ & $\begin{array}{l}1.02 * * \\
(0.097)\end{array}$ \\
\hline$\Delta \log ($ nonfinancial firms $) \times \mathrm{QE} 2$ & $\begin{array}{l}1.29 * * \\
(0.068)\end{array}$ & $\begin{array}{l}1.31 * * \\
(0.067)\end{array}$ & $\begin{array}{l}1.08 * * \\
(0.075)\end{array}$ & $\begin{array}{l}1.04 * * \\
(0.091)\end{array}$ \\
\hline$\Delta \log ($ nonfinancial firms $) \times \mathrm{QE} 3$ & $\begin{array}{l}1.19 * * \\
(0.10)\end{array}$ & $\begin{array}{l}1.15^{* *} \\
(0.12)\end{array}$ & $\begin{array}{l}0.76^{* *} \\
(0.047)\end{array}$ & $\begin{array}{r}0.78 * * \\
(0.055)\end{array}$ \\
\hline$\Delta \log ($ nonfinancial firms $) \times F G$ & $\begin{array}{r}1.39^{* *} \\
(0.091)\end{array}$ & $\begin{array}{l}1.38 * * \\
(0.079)\end{array}$ & $\begin{array}{l}1.36^{* *} \\
(0.21)\end{array}$ & $\begin{array}{l}1.27^{* *} \\
(0.17)\end{array}$ \\
\hline $\begin{array}{l}\Delta \log (\text { nonfinancial firms }) \times \mathrm{QE} 1 \\
\times>30 \text { minutes }\end{array}$ & & $\begin{array}{c}0.31 \\
(0.37)\end{array}$ & & $\begin{array}{c}0.13 \\
(0.19)\end{array}$ \\
\hline $\begin{array}{l}\Delta \log (\text { nonfinancial firms }) \times \mathrm{QE} 2 \\
\times>30 \text { minutes }\end{array}$ & & $\begin{array}{c}-0.094 \\
(0.14)\end{array}$ & & $\begin{array}{c}0.19 \\
(0.15)\end{array}$ \\
\hline $\begin{array}{l}\Delta \log (\text { nonfinancial firms }) \times Q E 3 \\
\quad \times>30 \text { minutes }\end{array}$ & & $\begin{array}{c}0.20 \\
(0.15)\end{array}$ & & $\begin{array}{c}-0.087 \\
(0.089)\end{array}$ \\
\hline $\begin{array}{l}\Delta \log (\text { nonfinancial firms }) \times F G \\
\times>30 \text { minutes }\end{array}$ & & $\begin{array}{r}0.065 \\
(0.19)\end{array}$ & & $\begin{array}{c}0.39 \\
(0.40)\end{array}$ \\
\hline$R^{2}$ & 0.763 & 0.766 & 0.705 & 0.711 \\
\hline Half-hour clusters & 65 & 65 & 65 & 65 \\
\hline No. of observations & 325 & 325 & 325 & 325 \\
\hline
\end{tabular}

a. The dependent variable is the 5-minute log change in the value-weighted stock price index of the sector indicated in the table heading. The right-hand-side variables are the 5-minute log change of a value-weighted index of all companies in the S\&P 500, excluding those in banking or insurance, interacted with QE or FG (forward guidance) round, and possibly with whether the 5-minute window occurs more than 30 minutes after the policy announcement, as indicated. The sample begins on each date at the time of the announcement and continues in non-overlapping 5-minute intervals for the shorter of two hours or until the end of the trading day at 4 p.m. Eastern time. Standard errors in parentheses and clustered by half-hour intervals. Statistical significance indicated at the +10 percent, $* 5$ percent, and $* * 1$ percent levels, respectively.

log change in the nonfinancial index, allowing the coefficients to vary by monetary policy round (QE1, QE2, QE3, or forward guidance). The estimated coefficients have the interpretation of CAPM $\beta$ s, with the important caveat that I have removed any mechanical correlation by restricting the market index to exclude banks and insurers.

Columns 1 and 3 report the loadings. I cluster standard errors using 30-minute interval bins. Similar to the analysis above, even at 5-minute intervals the stock prices of both life insurers and banks closely track nonfinancial firms following monetary policy announcements. The estimated $\beta$ for life insurers during QE1 reaches nearly 2, confirming that life insurers' 
stock prices reacted more strongly during that period than the market average. The life insurer $\beta$ falls to 1.19 during QE3, but still indicates that the stock prices of life insurers reacted in the same direction as the broader market, even in 2013. These $\beta$ s roughly track the pattern of life insurer $\beta$ s on nonannouncement dates as well (not shown in the table).

Columns 2 and 4 add separate coefficients for intervals beyond the initial 30-minute window (> $30 \mathrm{~min}$.) following the announcement. If markets required additional time on each date to realize that monetary policy should have an opposite effect on life insurers from its effect on the broader market, the coefficients on the market change interacted with $>30$ min. should enter with a negative sign. More generally, these coefficients test whether the co-movement between life insurers or banks and the broader market during the initial 30-minute window persisted thereafter, or whether instead investors began to differentiate these sectors as they had additional time to interpret the information in the announcement.

I find no evidence of differential effects as the window lengthens. None of the $>30 \mathrm{~min}$. coefficients achieves statistical significance, all are small in magnitude relative to the main coefficients, and including them has only a minor effect on the main coefficients. In short, the time profile of the reaction of life insurers and banks appears to be similar to that of the broader stock market. ${ }^{25}$ Robustness to longer window length should not be surprising in light of the CDS spread results reported in the previous sections. In most cases, the quasi-intra-day window for the CDS spread already went to the market close, so any reversal in perception would have resulted in changes in CDS spreads inconsistent with the equity changes using the shorter window.

\section{Money Market Funds}

Money market funds provide liquidity services to institutional and retail clients. The interaction of three features of money market funds in the United States makes them a potential concern for financial stability at low

25. Repeating the analysis of equity prices in table 2 using a 2 -hour window also gives qualitatively similar results (not shown). The winter 2008-09 announcements continue to have large positive effects. The most important difference comes in response to the September 18, 2013, announcement. Stock prices of a few of the largest insurers, including Prudential, MetLife, and Lincoln National, rose immediately following the FOMC statement but began to fall about 30 minutes later. Also around that time, news leaked to the press of a regulatory vote the following day on designating Prudential a systemically important institution, a development with potential implications for the other large life insurers as well. This again serves to highlight the usefulness of short windows. 
nominal interest rates ${ }^{26}$ First, money market funds maintain a stable net asset value of one dollar per share. They do so by valuing assets at amortized cost and providing daily dividends as securities progress toward their maturity date. ${ }^{27}$ Investors can redeem shares at the par net asset value even if the shadow market value has fallen below it. This feature makes funds subject to runs. ${ }^{28}$ Second, the Securities and Exchange Commission imposes duration, risk, and concentration limits on a fund's asset holdings (SEC rule 2a-7). Funds choose investments subject to these limitations. Third, money market funds charge fees, also called expense ratios, typically on a pro rata basis. The expense ratios do not affect the net asset value calculation, which depends solely on the amortized value of the fund's security holdings. However, they do affect a fund's total net return.

In normal conditions, the spread between the return on funds' assets and the interest rate on checking accounts easily accommodates the expense ratios. When nominal interest rates approach zero, however, the gross yield on funds' assets may fall short of their normal charged expenses. An afterfee return below zero would prompt investors to move into hard currency or bank deposit accounts that do not charge fees. A fund's sponsor can suspend the fees, implying an operational loss to the sponsor for keeping the fund open. Alternatively, funds may seek higher-yield investments within the allowed asset classes - reach for yield - to avoid having to waive fees. If the additional risk causes some of a fund's securities to lose even a small

26. Shortly before this paper went to press, the SEC adopted significant reforms of the money market fund sector not described here. These are available at www.sec.gov/rules/ final/2014/33-9616.pdf.

27. An example, adapted from the Investment Company Institute (2011), helps to clarify. Treasury bills sell as discount securities, meaning a 91-day Treasury bill with a face value of $\$ 100$ and an interest rate of 1.2 percent will pay no coupons and sell at auction for $\$ 99.70=\$ 100(1-0.012)^{1 / 4}$. A money market fund that acquired the security on the auction date would book the security at $\$ 99.70$. Under straight-line amortization, on each day until maturity the booked value of the security would rise by $\frac{\$ 100-\$ 99.70}{91}=\$ 0.0033$. The fund would balance the increase in the value of its assets by increasing its daily dividend by the same $\$ 0.0033$, thereby maintaining the stable net asset value of $\$ 1$ per share.

28. The so-called "penny rounding rule" requires a fund's board of directors to consider repricing the fund's shares ("break the buck") if the shadow market value falls 0.5 percent below the par net asset value. Funds must calculate their shadow market value on a periodic basis, with the interval determined by the board of directors. Thus the shadow price can fall well below 0.995 before the fund suspends redemptions at the par value. Furthermore, many of the assets held by funds, especially prime funds, do not have liquid secondary markets. If the fund must sell assets to satisfy redemptions, the market value may fall further as fire sale prices generate additional capital losses. See Securities and Exchange Commission (2013, pp. 14-19) for further discussion of the mechanics of a run on a money market fund. 
amount of value, the fund may have to "break the buck," causing a broad run on money market funds similar to what ensued following the Reserve Primary Fund's breaking the buck in September 2008..$^{29}$ Importantly, a single fund will not internalize the social costs of a broad run in the event that its additional risk exposure causes its assets to lose value.

I begin by describing how money market funds have adjusted their fees. Data on asset holdings, yields, and administrative costs come from iMoneyNet. As shown in online appendix figure C.2, the coverage of these data matches that of the Financial Accounts of the United States. I follow Marcin Kacperczyk and Philipp Schnabl (2013) and aggregate asset holdings, yields, and expenses up to the fund level using share class asset shares as weights. Table 5 displays summary statistics for 2006 and 2013.

Figure 10 shows a scatterplot of incurred expenses (horizontal axis) and charged expenses (vertical axis). Incurred expenses are meant to reflect the cost of running the fund, including management fees and advertising, while charged expenses are the fees actually paid by investors. Data points below the 45-degree line indicate funds that have waived part of their fees. The round dots show the relationship in 2006; most of them lie on the 45 -degree line or slightly below it. The data also indicate substantial dispersion in fees charged, with a mean of 0.54 and a standard deviation of 0.27 (see table 5, top two rows). ${ }^{30}$ The triangles show the relationship in 2013, and almost all lie well below the 45-degree line. They also show a substantial decline and compression in fees charged in 2013, with the mean falling to 0.14 and the standard deviation falling to 0.06 . The last two rows of table 5, labeled "7-day net compound yield," shed further light, reporting summary statistics for the average net (after-fee) yield, annualized, that an investor would earn if she reinvested the dividends received each week. In 2013, the average yield was 2 basis points, with a median of 1 and a 90th percentile of 4 basis points.

29. McCabe (2010) and Kacperczyk and Schnabl (2013) study the behavior of prime money market funds between the onset of the subprime crisis and the Lehman Brothers bankruptcy. The subprime crisis sparked a revaluation of risk and an opening of yield differentials among eligible AAA securities. Some funds responded by investing in higher-yield securities within the AAA class, prompting institutional investors to reallocate their investments to higher-yield funds and further increasing the incentive for a fund to reach for yield. Beginning in August 2007, the Reserve Primary Fund offered a yield of roughly 20 basis points higher than competitor funds, in part by purchasing large quantities of Lehman Brothers commercial paper, generating large inflows into the fund until the Lehman Brothers bankruptcy forced it to break the buck (Kacperczyk and Schnabl 2013, figure III).

30. See Christoffersen and Musto (2002) for a discussion of the reasons for the dispersion in fees charged. 
Table 5. Money Market Fund Summary Statistics, 2006 and 2013

\begin{tabular}{|c|c|c|c|c|c|c|}
\hline & & & & & & \\
\hline & Mean & $\begin{array}{l}\text { Standard } \\
\text { deviation }\end{array}$ & P10 & P50 & $P 90$ & $\begin{array}{c}\text { No. of } \\
\text { observations }\end{array}$ \\
\hline Charg & pense $r$ & innual aver & & & & \\
\hline 2006 & 0.54 & 0.27 & 0.20 & 0.53 & 0.93 & 685 \\
\hline 2013 & 0.14 & 0.06 & 0.07 & 0.13 & 0.22 & 469 \\
\hline Incurr & pense $r$ & innual aver & & & & \\
\hline 2006 & 0.65 & 0.33 & 0.27 & 0.62 & 1.03 & 685 \\
\hline 2013 & 0.57 & 0.35 & 0.23 & 0.52 & 0.98 & 469 \\
\hline 7-day & simple & annual ave & & & & \\
\hline 2006 & 4.40 & 0.82 & 3.39 & 4.92 & 5.06 & 685 \\
\hline 2013 & 0.16 & 0.06 & 0.09 & 0.14 & 0.25 & 469 \\
\hline 7-day & simple & standard d & & & & \\
\hline 2006 & 0.33 & 0.12 & 0.23 & 0.35 & 0.39 & 685 \\
\hline 2013 & 0.03 & 0.01 & 0.02 & 0.03 & 0.04 & 469 \\
\hline 7-day & ompoun & $d$, annual a & & & & \\
\hline 2006 & 3.94 & 0.90 & 2.73 & 4.30 & 4.90 & 685 \\
\hline 2013 & 0.02 & 0.02 & 0.00 & 0.01 & 0.04 & 469 \\
\hline
\end{tabular}

a. This table reports cross-sectional statistics, by year, of time-series properties at the fund level.

Figure 10. Money Market Fund Expense Ratios, 2006 and 2013

Charged expenses as percent of assets

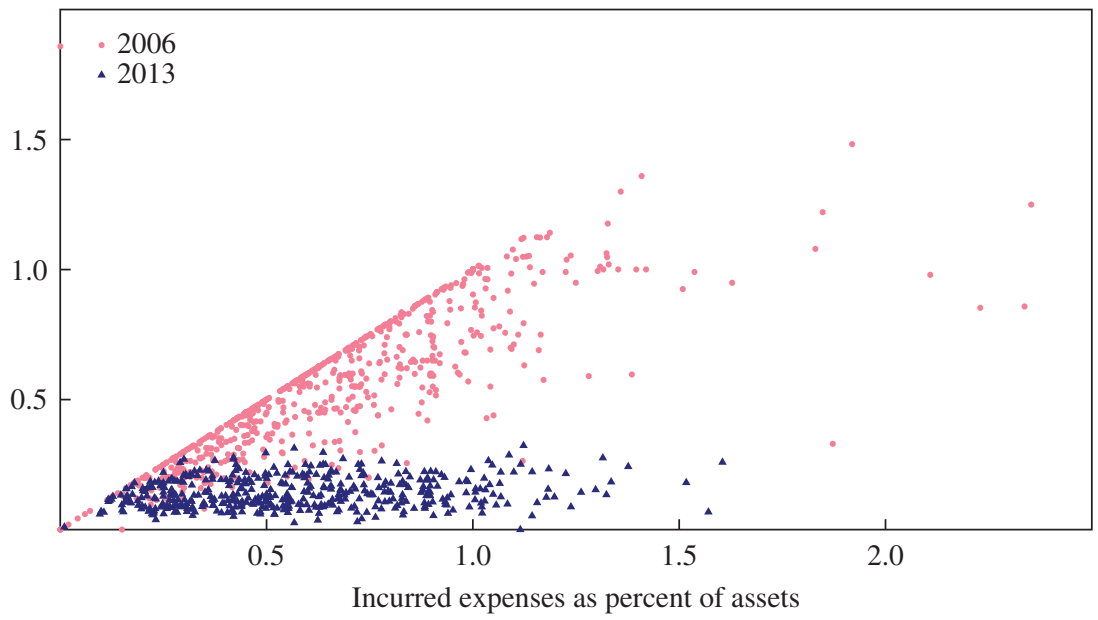

a. To enhance readability, the figure omits one 2013 fund with $\$ 6$ million under management, incurred expenses of 4.6 percent, and charged expenses of 0.04 percent. 
Figure 11. Determinants of Money Market Fund Charged Expenses, 2006-13

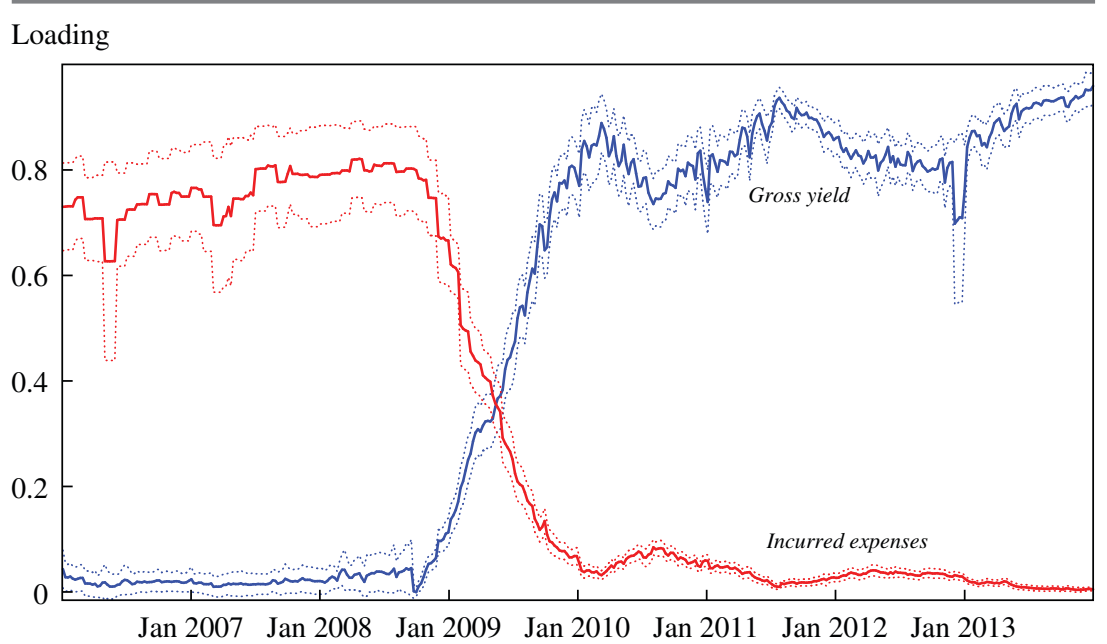

a. The solid lines plot the weekly coefficients from an OLS regression of charged expenses on week fixed effects, gross yield, and incurred expenses. Equation 5 (see text) provides the estimating equation. The dotted lines plot 95 percent confidence interval bands based on standard errors clustered by fund sponsor. The regression winsorizes observations with the smallest and largest 0.01 percent of incurred expenses.

The compression of net yields and the ubiquity of fee waivers suggest that money market funds responded to the low-interest-rate environment by waiving just enough of their fees to ensure their investors received a non-negative nominal return. I confirm this interpretation by estimating the following regression by fund share class and at a weekly frequency:

$$
\begin{aligned}
\text { Charged expenses }_{i, t}= & \alpha_{t}+\beta_{t}\left[\text { Gross yield }_{i, t}\right] \\
& +\gamma_{t}\left[\text { Incurred expenses }_{i, t}\right]+e_{i, t} .
\end{aligned}
$$

Equation 5 allows non-parametrically for time-varying loadings of charged expenses on the gross (before-fee) yield (the $\beta_{t}$ ) and on the costs of running the fund (the $\gamma_{t}$ ). Inclusion of week fixed effects limits identification to coming from variation across funds in a given week.

Figure 11 reports the estimated $\left\{\beta_{t}\right\}$ as a solid line and $\left\{\gamma_{t}\right\}$ as a dashed line. Prior to late 2008, the marginal basis point of gross yield has essentially no effect on the charged fee, whereas a 10-basis-point increase in incurred expenses corresponds to an increase of roughly 8 basis points in 
fees charged. The relationship reverses completely after gross yields fall to close to zero. From 2010 to 2013, an additional 10 basis points in gross yield corresponds to 9 additional basis points in charged fees, while the marginal basis point of incurred expenses has no effect on charged fees. ${ }^{31}$ The almost complete pass-through of higher gross returns to higher charged fees suggests that the funds' operators were aware of the cost of waiving fees and the potential to avoid such costs by generating higher gross returns - reaching for yield.

I therefore test in the cross-section of funds whether funds with higher structural administrative costs reached for yield. I examine four measures of reaching for yield: the gross yield, the ex-post realized standard deviation of monthly excess returns, the share of holdings in foreign bank obligations net of repurchase agreements (repo), and the average asset maturity. The gross yield captures directly whether a fund has successfully reached for yield. The ex-post standard deviation measures risk. Figure 13 shows that during most of the unconventional monetary policy period, foreign bank obligations are the highest yield asset class and repo are the lowest. The average asset maturity provides a measure of reaching for yield through reaching for maturity. ${ }^{32}$

I assume a data generating process for each measure of the form

$$
y_{i, t}=\alpha_{i}+\delta_{t}+\beta_{t}[\text { Administrative costs }]_{i, t}+\gamma_{t}^{\prime} x_{i}+e_{i, t} .
$$

The identifying assumption is that funds with high and low management costs do not differ along other features that would make them respond differently to low nominal interest rates. The fund fixed effect $\alpha_{i}$ absorbs time-invariant unobserved fund characteristics, such as managerial skill. The time effect $\delta_{t}$ controls for variation in the macroeconomic environment, such as changes in short-term interest rates. For the two ex-post measures of gross yield and standard deviation of returns, the vector $x_{i}$ includes the

31. I have also estimated a specification replacing the weekly fixed effects with fund $\times$ year fixed effects, such that identification comes from variation within a single fund over the course of the year. I obtain coefficients of $0.86,0.84$, and 0.90 for the loadings on gross yield in 2011, 2012 , and 2013, respectively, up from 0.00 in 2007. These loadings mirror almost exactly those shown in figure 11. Absence of within-fund variation in incurred expenses, however, renders the loadings on incurred expenses very imprecisely estimated with the fund fixed effects.

32. Kacperczyk and Schnabl (2013) also use the gross yield and average maturity measures. I adapt their measure of risky asset holdings based on the asset class loadings during my sample period. 
observed fund characteristics of fund category (tax-free, prime, or U.S. government and agency securities and backed repo), whether the fund has any institutional shares, and 2005 portfolio allocation by asset class category. Because credit spreads vary during the sample period, a fund could obtain higher yield or more variable returns in certain periods without having changed its asset composition. The time-varying loadings in $\gamma_{t}$ absorb fluctuations due to time-invariant asset allocation into the control set, limiting reaching for yield to fluctuations resulting from an active decision on the part of the fund manager. Finally, because incurred expenses may serve as an imperfect proxy for administrative costs and because funds may endogenously adjust incurred expenses in the low-interest-rate environment, I instrument for a fund's incurred expenses using the fund's 2005 incurred expenses.

Table 6 reports results using annual average data for a balanced panel of funds over the 2006-13 period. I cluster standard errors at the fundsponsor level, thus allowing for both arbitrary serial correlation and arbitrary correlation across funds with the same sponsor. The table reports the first stage F statistics for 2013 expenses, showing 2005 incurred expenses to be a strong instrument. Identification of the unobserved characteristics $\alpha_{i}$ requires imposing $\beta_{t}=0$ for at least one year, and I set $\beta_{2006}=0$. The nearzero coefficients across specifications for $\beta_{t}$ in the normal interest rate year of 2007 both justify this restriction and serve as a useful placebo check.

Table 6 provides evidence of money market funds reaching for yield in 2009-11. However, the effects appear quite small in economic terms. For example, the 2010 coefficient for the gross yield measure achieves statistical significance at the 1-percent level, but it has the interpretation of a 1-percentage-point (or roughly three standard deviation) increase in administrative costs resulting in an additional 6 basis points of annualized gross yield. Likewise, 2011 incurred expenses have a statistically strong effect on the standard deviation of returns, but a 1-percentage-point increase in expenses still results in an increase of the standard deviation of just 1.8 basis points. Both the gross yield and standard deviation measures indicate that incurred expenses have a precise zero effect on reaching for yield in 2013, the most recent data available. The asset allocation and maturity measures indicate no differences in allocations among funds with high and low costs.

Figure 12 further explores the timing of reaching-for-yield behavior. The figure plots the second-stage coefficient on incurred expenses from a weekly regression using gross yield as the dependent variable, the weekly incurred expenses instrumented using the 2005 values, a fund fixed effect 
Table 6. Money Market Fund Reaching for Yield (Regressions) ${ }^{\mathrm{a}}$

\begin{tabular}{|c|c|c|c|c|}
\hline \multirow[b]{2}{*}{$\begin{array}{l}\text { Right-hand-side } \\
\text { variables }\end{array}$} & \multicolumn{4}{|c|}{ Dependent variable } \\
\hline & $\begin{array}{l}\text { Gross yield }^{\mathrm{b}} \\
\text { (1) }\end{array}$ & $\begin{array}{c}\text { Standard } \\
\text { deviation } \\
\text { return }{ }^{c} \\
\text { (2) }\end{array}$ & $\begin{array}{c}\text { Risky asset } \\
\text { allocation }^{\mathrm{d}} \\
\text { (3) }\end{array}$ & $\begin{array}{c}\text { Average } \\
\text { maturity } \\
\text { (4) }\end{array}$ \\
\hline $\begin{array}{l}2007 \text { incurred expenses } \\
\text { (IV: } 2005 \text { value) }\end{array}$ & $\begin{array}{c}0.000 \\
(0.011)\end{array}$ & $\begin{array}{c}0.006 \\
(0.011)\end{array}$ & $\begin{array}{c}1.482 \\
(2.302)\end{array}$ & $\begin{array}{c}0.496 \\
(1.471)\end{array}$ \\
\hline $\begin{array}{l}2008 \text { incurred expenses } \\
\text { (IV: } 2005 \text { value) }\end{array}$ & $\begin{array}{r}0.125^{+} \\
(0.076)\end{array}$ & $\begin{array}{c}0.060 \\
(0.045)\end{array}$ & $\begin{array}{c}0.630 \\
(4.007)\end{array}$ & $\begin{array}{c}-1.833 \\
(2.067)\end{array}$ \\
\hline $\begin{array}{l}2009 \text { incurred expenses } \\
\text { (IV: } 2005 \text { value) }\end{array}$ & $\begin{array}{r}0.184^{*} \\
(0.078)\end{array}$ & $\begin{array}{c}0.058 \\
(0.041)\end{array}$ & $\begin{array}{l}-0.725 \\
(4.808)\end{array}$ & $\begin{array}{l}-2.996 \\
(2.535)\end{array}$ \\
\hline $\begin{array}{l}2010 \text { incurred expenses } \\
\text { (IV: } 2005 \text { value) }\end{array}$ & $\begin{array}{l}0.064 * * \\
(0.016)\end{array}$ & $\begin{array}{c}0.010 \\
(0.007)\end{array}$ & $\begin{array}{c}-0.744 \\
(5.333)\end{array}$ & $\begin{array}{c}-2.091 \\
(2.106)\end{array}$ \\
\hline $\begin{array}{l}2011 \text { incurred expenses } \\
\text { (IV: } 2005 \text { value) }\end{array}$ & $\begin{array}{r}0.049 * \\
(0.024)\end{array}$ & $\begin{array}{l}0.018 * * \\
(0.005)\end{array}$ & $\begin{array}{c}2.571 \\
(7.387)\end{array}$ & $\begin{array}{c}-1.549 \\
(3.289)\end{array}$ \\
\hline $\begin{array}{l}2012 \text { incurred expenses } \\
\text { (IV: } 2005 \text { value) }\end{array}$ & $\begin{array}{c}0.029 \\
(0.019)\end{array}$ & $\begin{array}{c}0.011 \\
(0.008)\end{array}$ & $\begin{array}{c}5.952 \\
(7.299)\end{array}$ & $\begin{array}{l}-5.504 \\
(4.024)\end{array}$ \\
\hline $\begin{array}{l}2013 \text { incurred expenses } \\
\text { (IV: } 2005 \text { value) }\end{array}$ & $\begin{array}{c}0.013 \\
(0.012)\end{array}$ & $\begin{array}{c}0.002 \\
(0.005)\end{array}$ & $\begin{array}{c}1.362 \\
(7.504)\end{array}$ & $\begin{array}{c}-4.455 \\
(3.749)\end{array}$ \\
\hline Sample period & 2006-13 & 2006-13 & 2006-13 & $2006-13$ \\
\hline Fund fixed effects & Yes & Yes & Yes & Yes \\
\hline Year fixed effects & Yes & Yes & Yes & Yes \\
\hline Time-varying controls ${ }^{\mathrm{f}}$ & Yes & Yes & No & No \\
\hline 2013 first-stage $F$ statistic & 149.6 & 149.6 & 382.0 & 352.3 \\
\hline Unique funds & 379 & 379 & 135 & 379 \\
\hline Fund sponsor clusters & 76 & 76 & 65 & 76 \\
\hline No. of observations & 3,032 & 3,032 & 1,080 & 3,032 \\
\hline
\end{tabular}

a. Standard errors in parentheses and clustered by fund sponsor. Statistical significance indicated at the +10 percent, $* 5$ percent, and $* * 1$ percent levels, respectively

b. The gross yield is the annual average of the weekly gross simple yield.

c. The standard deviation is the annual standard deviation of the monthly excess return, defined as the gross return less the 1-month Treasury bill.

d. The risky asset allocation equals the asset share in foreign bank obligations less the share in repo, and for this regression the sample excludes non-prime funds.

e. The average maturity refers to the average of the maturity of a fund's securities, in days.

f. The time-varying controls are categorical variables, interacted with year, for fund category (tax-free, prime, or U.S. government and agency securities and backed repo), 2005 portfolio share by asset class, and for whether the fund has any institutional shares.

identified from including observations from 2006, and the full set of timevarying controls described previously. Thus the specification corresponds to column 1 of table 6 , except that the effect of administrative costs may vary at a weekly frequency. Consistent with the annual regressions, costs have a zero or even negative effect on gross yield until late 2008. The spike in the estimated coefficient occurs in the beginning of October 2008, the month in 
Figure 12. Loading of Gross Yield on Incurred Expenses, by Week, 2007-13

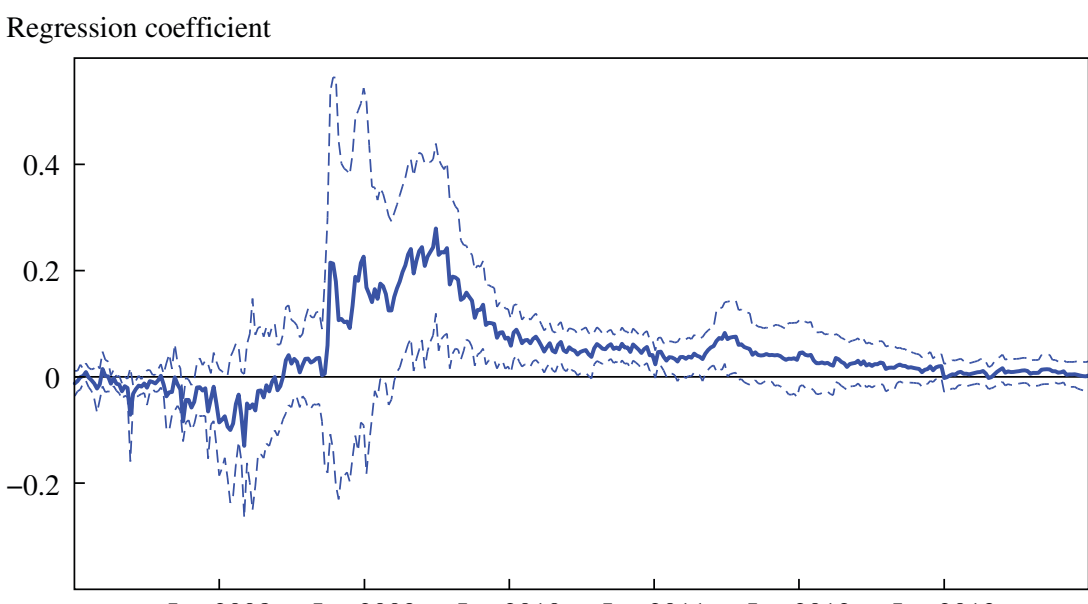

Jan 2008 Jan $2009 \quad$ Jan $2010 \quad$ Jan $2011 \quad$ Jan $2012 \quad$ Jan 2013

a. The solid line plots the coefficients from a weekly regression of gross yield on incurred expenses, with incurred expenses instrumented using their 2005 average value. The regression also contains fund fixed effects identified by including observations from 2006, and fund type and asset class holdings in 2005 interacted with week. Sample excludes fund-weeks with a gross yield of zero. The dotted lines plot 95 percent confidence interval bands based on standard errors clustered by fund sponsor.

which the average yield on a 1-month Treasury bill first fell below 50 basis points. The reaching behavior remains statistically significant through the middle of 2011 and falls to a precise zero throughout 2013.

What explains the relative absence of reaching-for-yield behavior compared to the period during the subprime crisis? And what explains the dissipation of such behavior in 2013? Figure 13 displays 3-month centered moving averages of coefficients from a weekly regression of gross yield on the allocation to each asset class. As stressed by Kacperczyk and Schnabl (2013), the subprime crisis created large return differentials from investing in different asset classes. Many prime funds responded by concentrating their holdings in higher yield classes. These differentials compressed substantially beginning in mid-2009, and by 2013 they had reached historically low levels. Such small differentials provide little opportunity for prime funds to reach for yield through asset class allocation. ${ }^{33}$

33. Of course, reaching for yield could return if spreads open up again, for example due to renewed sovereign risk concerns in Europe. Even so, the first-best policy response should involve further reform of the money market sector to remove the threat of runs, rather than changing monetary policy. 
Figure 13. Money Market Fund Yields by Category, 2006-13

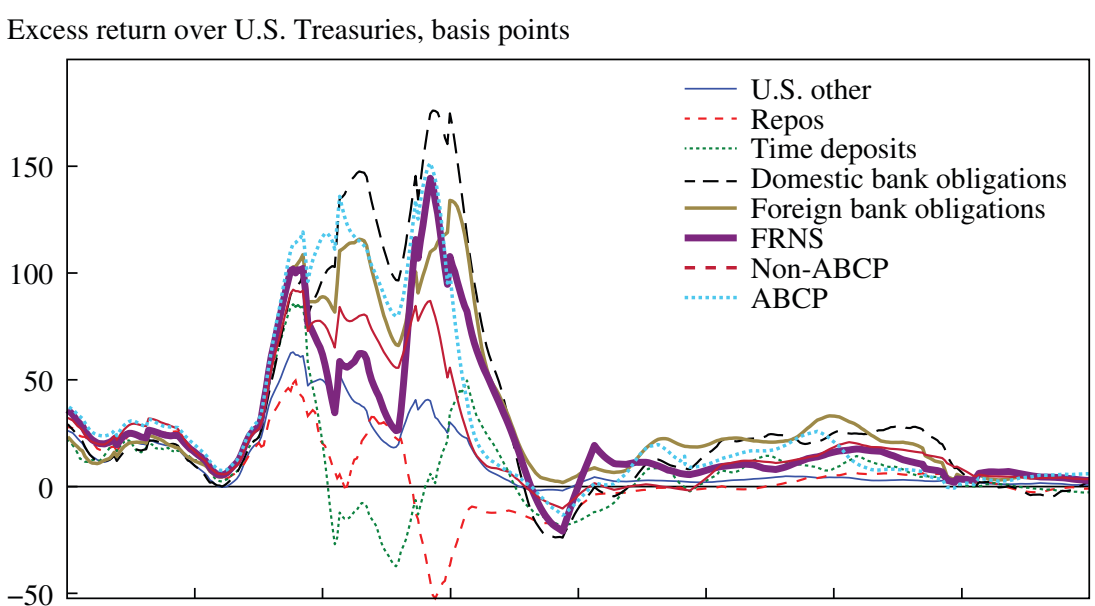

Jan 2007 Jan 2008 Jan 2009 Jan 2010 Jan 2011 Jan 2012 Jan 2013

a. The figure plots the 3-month centered moving average of coefficients from a weekly regression of gross yield on the asset allocation in the categories shown. U.S. Treasuries are the omitted category, and the sample includes all taxable money market funds. The regression also includes a fund fixed effect allowed to vary by calendar year.

A second explanation of the 2012 and 2013 results stems from a set of reforms implemented by the Securities and Exchange Commission in mid2010. These included reducing the allowable fraction of assets in illiquid securities, the weighted-average maturity of assets, the fraction of assets in second-tier securities, and the concentration limit for securities issued by any single issuer. In distinguishing between these two explanations, the timing of the decline in reaching for yield, and especially the absence in figure 12 of a series break in mid-2010 when the reforms came into effect, suggests the compression in yields may have played a more important role.

Although the link between charged fees and gross yields has not produced much reaching for yield by money market funds, it still has a potentially important implication for constraints on Federal Reserve policy. Even with the introduction of the extraordinary policy measures described above, the FOMC since 2009 has maintained a target federal funds rate between 0 and 25 basis points and paid interest on excess reserves of 25 basis points. One justification for not reducing both of these rates to zero has centered on the risk of disruptive outflows from money market funds forced into a negative after-fee return. Yet funds already subsidize investors by waiving fees. Figure 11 suggests that funds might respond to a further decline in 
gross yields by simply waiving fees completely, leaving investors with the same net yield of zero that they currently receive.

Reducing both the federal funds rate and the interest on reserves to zero could prompt further consolidation of the money market industry. The fee waivers to date have already induced substantial exit, as seen both in the decline in the number of funds by year (in table 5) and by the trilliondollar decline in total assets under management since early 2009 (shown in online appendix figure C.2). Many of the remaining funds receive crosssubsidization from their sponsors' other lines of business, and some of these could exit if the required subsidization rises further. Nonetheless, further consolidation need not harm financial stability or the transmission of monetary policy as long as it continues to occur in an orderly fashion, as it has done since 2009.

\section{Pension Funds}

Private defined-benefit pension funds manage roughly $\$ 3$ trillion in retirement assets. I start from two previously documented dimensions of heterogeneity in fund risk taking in normal conditions. First, funds reduce risk exposure as liability duration decreases (Lucas and Zeldes 2006; Rauh 2009). Second, funds with a higher fraction of unfunded liabilities engage in less risk taking, in opposition to a risk-shifting hypothesis where underfunded plans "reach for solvency" because of limited liability in the event a pension shortfall pushes the plan into bankruptcy (Rauh 2009).

I investigate whether fund behavior along these dimensions changes in the low-interest-rate environment. For example, having a short duration of liabilities in a period of low interest rates following a market downturn might lead funds to increase risk taking, since they have less time to make up any funding shortfall. Similarly, since low interest rates exacerbate a funding shortfall by making it harder to close the gap through higher returns, this too might lead to greater risk taking.

I collect data on private pension funds from the form 5500 reports on funds filed with the IRS. Plans with 100 or more participants must file a schedule $\mathrm{H}$, containing a detailed asset and income statement, and a schedule B (SB or MB after 2009) showing their funding status. Online appendix A contains further details of the sample construction and filters.

The first metric of risk taking uses the fund's reported investment earnings to construct an annual return on assets, defined as total earnings on investments (including unrealized capital gains) divided by the sum of beginning-of-period assets plus one-half of net contributions. A second 
Table 7. Defined-Benefit Pension Fund Summary Statistics, 2006-12a

\begin{tabular}{|c|c|c|c|c|c|c|c|c|}
\hline \multirow[b]{2}{*}{ Year } & \multirow{2}{*}{$\begin{array}{c}S \& P \\
500 \\
\text { return }\end{array}$} & \multicolumn{2}{|c|}{ Fund return } & \multicolumn{2}{|c|}{ Expenses/assets } & \multicolumn{2}{|c|}{ Benefits/assets } & \multirow[b]{2}{*}{$\begin{array}{c}\text { No. of } \\
\text { observations }\end{array}$} \\
\hline & & Mean & $\begin{array}{l}\text { Standard } \\
\text { deviation }\end{array}$ & Mean & $\begin{array}{l}\text { Standard } \\
\text { deviation }\end{array}$ & Mean & $\begin{array}{l}\text { Standard } \\
\text { deviation }\end{array}$ & \\
\hline 2006 & 13.6 & 11.2 & 2.6 & 0.06 & 0.03 & 1.13 & 0.22 & 4225 \\
\hline 2007 & 3.5 & 7.2 & 2.5 & 0.06 & 0.03 & 1.1 & 0.22 & 4225 \\
\hline $2008^{b}$ & -38.5 & -22.1 & 7.3 & 0.06 & 0.03 & & & 4225 \\
\hline 2009 & 23.5 & 18.3 & 6.1 & 0.08 & 0.04 & 1.16 & 0.18 & 4225 \\
\hline 2010 & 12.8 & 11.6 & 2.8 & 0.07 & 0.03 & 1.19 & 0.16 & 4225 \\
\hline 2011 & 0.0 & 1.7 & 3.9 & 0.06 & 0.03 & 1.24 & 0.17 & 4225 \\
\hline 2012 & 13.4 & 11.3 & 2.9 & 0.07 & 0.04 & 1.09 & 0.16 & 4225 \\
\hline
\end{tabular}

a. This table reports cross-sectional statistics, by year.

b. Data for funding status in 2008 are not available from the Department of Labor.

metric divides the sample into two periods, 2004-08 and 2009-12, and constructs the standard deviation of the fund's return in each period. Table 7 reports summary statistics for a balanced panel of pension plans. Of note, the mean return tracks the return on the S\&P 500 reasonably closely. ${ }^{34}$

Equation 7 describes a difference-in-differences specification for estimating the effect of a pension plan measure on the ex-post annual return:

$$
\begin{aligned}
r_{i, t}= & \delta_{t}+\pi_{t}^{\prime} Z_{i}+\gamma\left[r_{m, t}^{e}\right][\text { Plan measure }]_{i, t} \\
& +\mathbb{I}\{t>2006\} \gamma_{t}\left[r_{m, t}^{e}\right][\text { Plan measure }]_{i, t}+e_{i, t},
\end{aligned}
$$

where $r_{i, t}$ denotes fund $i$ 's return in period $t ;\left[r_{m, t}^{e}\right]$ is the Fama-French excess return of the stock market over the risk-free rate; and the vector of controls $Z_{i}$ includes fund size and age. Equation 7 defines reaching for yield as a fund's increasing its loading on the market excess return. ${ }^{35}$ The coefficient $\gamma$ gives the estimated loading per unit of the measure of plan status in 2006, and $\gamma_{t}$ gives the additional loading in subsequent years.

34. Rauh (2009) instead studies asset allocation using a subset of smaller plans which do not invest in Direct Filing Entities and for which asset allocation is available from the 5500 reports. The ex-post return and standard deviation of return have the advantage of applying to all defined-benefit plans.

35. According to the Federal Reserve's Financial Accounts of the United States (table L.117.b), in the aggregate, private defined-benefit pension funds held between 50 and 70 percent of their assets in equities between 2005 and 2013. These plans held an additional 15 percent of their assets in the "safe asset" categories of deposits, money market funds, repo, open market paper, Treasury securities, and agency securities. 
Equation 8 describes a difference-in-differences specification of the ex-post standard deviation of fund returns, over 2004-08 and 2009-12, and for funds with varying status as of the first year of the period (that is, 2004 or 2009):

$$
\begin{aligned}
\sigma\left(r_{i, t}\right)= & \delta_{t}^{s d}+\pi_{t}^{s d^{\prime}} Z_{i}+\gamma^{s d} \sigma\left(r_{m, t}\right)[\text { Plan measure }]_{i, t} \\
& +\gamma_{09-12}^{s d} \sigma\left(r_{m, t}\right)[\text { Plan measure }]_{i, 09}+\epsilon_{i, t}^{s s} .
\end{aligned}
$$

The first plan measure is the ratio of a fund's benefit expenses in a given year to its total assets. This measure captures the maturity horizon of liabilities. In equation $7, \gamma<0$ if plans with a shorter duration of liabilities allocate to safer assets. The coefficients $\left\{\gamma_{t}\right\}_{t=2007}^{2012}$ then ask whether these plans allocated relatively less to safer assets in the low-interest-rate environment. The coefficient $\gamma_{09}^{s d}$ in equation 8 gives the additional standard deviation of returns, scaled by the standard deviation of the market excess return, of funds with a shorter horizon in 2009.

The first two columns of table 8 report the results. The coefficients $\gamma$ and $\gamma^{\text {sd }}$ are both negative and highly statistically significant, consistent with the negative relationship between near-term liabilities and risk taking in Deborah Lucas and Stephen Zeldes (2006) and Joshua Rauh (2009). The coefficients $\gamma_{2007}$ and $\gamma_{2008}$ cannot reject a constant effect of liability duration before the low-interest-rate environment.

The regressions provide some evidence of reaching for yield beginning in 2009. The effect of liability duration on return falls by one-half to twothirds in 2009 and 2010, and the differences relative to 2006 are statistically significant at the 1- and 5-percent levels, respectively. Similarly, the decline in the loading on the standard deviation of the market excess return falls by about two-thirds for 2009-12 relative to 2004-08. While statistically significant, these differences do not translate into particularly large economic effects. For example, the difference in the loading on the market excess return in 2005 and 2009 for a fund that is one standard deviation (0.04) above the mean of expenses/assets is $0.52 * 0.04=0.02$. This difference corresponds to an additional return of about 50 basis points on the 2009 excess return of 28 percent. The effect on return loading loses statistical significance in 2011 and 2012. The large standard error in 2011 reflects the near-zero Fama-French excess return (0.44) in that year.

I next investigate the effects of plan solvency. Loosely, the Pension Protection Act of 2006 requires pension plans to value their assets at market prices and to value their liabilities using a combination of actuarial 
Table 8. Defined-Benefit Pension Fund Reaching for Yield (Regressions) ${ }^{\mathrm{a}}$

\begin{tabular}{|c|c|c|c|c|c|}
\hline \multirow[b]{4}{*}{ Right-hand-side variable } & \multicolumn{5}{|c|}{ Plan measure } \\
\hline & \multicolumn{2}{|c|}{ Benefits/assets } & \multicolumn{3}{|c|}{ Benefits NPV/assets } \\
\hline & \multicolumn{5}{|c|}{ Dependent variable (p.p.) } \\
\hline & $\begin{array}{c}r_{i, t} \\
(1)^{\mathrm{b}}\end{array}$ & $\begin{array}{c}\sigma\left(r_{i, t}\right) \\
(2)^{\mathrm{c}}\end{array}$ & $\begin{array}{c}r_{i, t} \\
(3)^{\mathrm{b}}\end{array}$ & $\begin{array}{c}\sigma\left(r_{i, t}\right) \\
(4)^{\mathrm{c}}\end{array}$ & $\begin{array}{c}r_{i, t} \\
(5)^{\mathrm{b}}\end{array}$ \\
\hline$r_{m}^{e \mathrm{~d}} \times($ plan measure $)$ & $\begin{array}{c}-0.67 * * \\
(0.12)\end{array}$ & & $\begin{array}{l}0.13 * * \\
(0.03)\end{array}$ & & \\
\hline $2006 \times r_{m}^{e}($ Plan measure $)$ & & & & & $\begin{array}{c}-0.07 * \\
(0.03)\end{array}$ \\
\hline $2007 \times r_{m}^{e}($ Plan measure $)$ & $\begin{array}{c}-0.32 \\
(1.14)\end{array}$ & & $\begin{array}{r}-0.45^{+} \\
(0.27)\end{array}$ & & $\begin{array}{c}0.63 \\
(0.55)\end{array}$ \\
\hline $2008 \times r_{m}^{e}(\text { Plan measure })^{e}$ & $\begin{array}{c}0.10 \\
(0.14)\end{array}$ & & & & \\
\hline $2009 \times r_{m}^{e}($ Plan measure $)$ & $\begin{array}{l}0.52 * * \\
(0.13)\end{array}$ & & $\begin{array}{l}0.33^{* *} \\
(0.03)\end{array}$ & & $\begin{array}{l}0.14 * * \\
(0.02)\end{array}$ \\
\hline $2010 \times r_{m}^{e}($ Plan measure $)$ & $\begin{array}{c}0.32 * \\
(0.14)\end{array}$ & & $\begin{array}{l}0.13^{* *} \\
(0.03)\end{array}$ & & $\begin{array}{c}0.04 \\
(0.03)\end{array}$ \\
\hline $2011 \times r_{m}^{e}($ Plan measure $)$ & $\begin{array}{c}0.41 \\
(3.47)\end{array}$ & & $\begin{array}{c}-6.38^{* *} \\
(1.01)\end{array}$ & & $\begin{array}{l}-5.32 * * \\
(1.32)\end{array}$ \\
\hline $2012 \times r_{m}^{e}($ Plan measure $)$ & $\begin{array}{c}0.08 \\
(0.17)\end{array}$ & & $\begin{array}{r}0.07^{+} \\
(0.04)\end{array}$ & & $\begin{array}{r}0.05^{+} \\
(0.03)\end{array}$ \\
\hline$\sigma r_{m}^{e} \times($ Plan measure $)$ & & $\begin{array}{c}-0.36^{* *} \\
(0.11)\end{array}$ & & $\begin{array}{c}0.01 \\
(0.02)\end{array}$ & \\
\hline $2009 \times \sigma r_{m}^{e} \times($ Plan measure $)$ & & $\begin{array}{c}0.24^{*} \\
(0.11)\end{array}$ & & $\begin{array}{l}0.18^{* *} \\
(0.03)\end{array}$ & \\
\hline Year FE & Yes & Yes & Yes & Yes & Yes \\
\hline Size, age controls ${ }^{\mathrm{f}}$ & Yes & Yes & Yes & Yes & No \\
\hline Fund FE & No & No & No & No & Yes \\
\hline Fund-specific $r_{m}^{e}$ loading & No & No & No & No & Yes \\
\hline Unique funds & 4,225 & 3,580 & 3,665 & 3,177 & 3,665 \\
\hline Fund sponsor clusters & 3,719 & 3,186 & 3,177 & 2,806 & 3,177 \\
\hline No. of observations ${ }^{\mathrm{g}}$ & 29,575 & 7,160 & 21,990 & 6,353 & 21,990 \\
\hline
\end{tabular}

a. Standard errors in parentheses and clustered by fund sponsor. Statistical significance indicated at the +10 percent, $* 5$ percent, and $* * 1$ percent levels, respectively.

b. The pension return $r_{i, t}$ is the annual earnings on investments divided by the sum of beginning of year assets plus one half net transfers and contributions.

c. $\sigma\left(r_{i, t}\right)$ is the standard deviation of the pension return over 2004-08 or 2009-12.

d. $r_{m}^{e}$ is the Fama-French stock market excess return.

e. Benefits NPV/assets are not available for 2008, and in all years specifications including this variable remove multiemployer $(\mathrm{MB})$ plans.

f. If included, size (log assets) and age controls interacted with year.

g. Observations with a distance to the median larger than five times the interquartile range are winsorized. 
assumptions to predict future payments and market interest rates to discount those cash outflows back into current dollars. ${ }^{36}$ Low interest rates contribute directly to underfunded status by lowering the discount rate used to discount future liabilities. The 2006 act also mandated that pension plans with funding shortfalls increase their contributions sufficiently to amortize their unfunded liability over a 7-year period. However, if a plan can realize a higher return on its assets than the rate used to discount liabilities, it can close the funding shortfall without requiring higher contributions. This creates a temptation to reach for yield. I measure funding shortfall as the ratio of the net present value of benefits to total assets.

Columns 3 and 4 of table 8 report results corresponding to equations 7 and 8 for the plan solvency measure. ${ }^{37}$ The difference-in-differences specification for the return standard deviation in column 4 indicates that funding shortfall has no effect on return standard deviation during 2004-08 but a strong positive relationship during 2009-12, consistent with reaching for yield. Results for equation 7 are more mixed. I find a negative relationship between funding shortfall and reaching for yield in the pre-low-interest-rate year of 2006, as in Rauh (2009). Funding shortfall has a small positive effect on return in 2009, 2010, and 2012, but a large negative effect in 2011.

The specifications so far rely on an assumption of parallel trends, namely that plans with differing liability horizons or solvency did not differ along other dimensions that would have caused their relative risk taking to change beginning in 2009. Column 5 of table 8 relaxes this assumption by exploiting the panel structure of the data. I assume the data-generating process

$$
r_{i, t}=\alpha_{i}+\delta_{t}+\beta_{i} r_{m, t}^{e}+\gamma_{t} r_{m, t}^{e}[\text { Plan measure }]_{i, t-1}+\epsilon_{i, t} .
$$

36. Specifically, single employer plans must discount future liabilities using the 2-year average of the yield on investment grade corporate bonds, with separate maturities of bonds used for liabilities due in 0 to 5 years, 5 to 15 years, and longer than 15 years. A 2012 law temporarily changed the horizon for averaging yields to 25 years, resulting mechanically in improved funding status. Plans can smooth asset values over a 2-year period as long as the difference between the smoothed actuarial valuation and fair market value does not exceed ten percent of the plan's assets. Also of relevance, the 2006 act applies the penalty premium for contributions to the Pension Benefit Guaranty Corporation to any underfunded plan, and it created the category of "at risk" plans, containing plans in particularly poor funding status and subjecting them to additional required contributions. Together, these changes make level comparisons of funded status reported on the 5500 forms across years inappropriate. Inclusion of time fixed effects helps to solve this problem by absorbing statutory changes into the time effects.

37. Data for funding status in 2008 are not available. Data are missing in select other years for a few plans. Results remain essentially unchanged when restricted to a balanced panel of funds not missing data in any non-2008 year. 


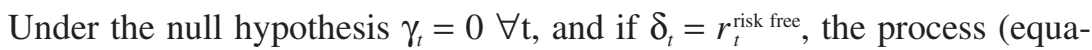
tion 9) collapses to a single-factor pricing model, with the market excess return being the single factor. The factor pricing model allows funds to have different permanent risk profiles through the fund-specific loading $\beta_{i}$ and fund-specific managerial skill through the fixed effect $\alpha_{i}$. The time effect $\delta_{t}$ controls for macroeconomic conditions such as the risk-free rate as well as changes in the definition of funding status that occurred throughout the sample period. Identification of $\gamma_{t}$ requires zero serial correlation of the residuals $\varepsilon_{i, t}{ }^{38}$

The fund fixed effect and fund-specific loading render equation 9 incompatible with return standard deviation the dependent variable and standard deviations computed over only two periods. Likewise, the correlation between liability horizon and risk taking, even absent low interest rates, and the deterministic nature of liability horizon violate the assumption of constant $\beta_{i}$ and could make $c_{i, t}$ correlated with the liability horizon. Therefore, I estimate equation 9 only for the plan solvency measure and for the ex-post return as the outcome variable.

The coefficients in column 5 appear reassuringly close to the total effects (main plus interaction) in column 3. Funds with larger shortfalls engage in less risk taking in the pre-low-interest-rate year of 2006. Funding shortfall has a small positive effect on return in 2009, 2010, and 2012, but again a large negative effect in 2011.

To review, there is evidence that some pension funds reached for yield in 2009. This finding appears using both measures of fund status and using either the level or standard deviation of returns to measure risk taking. The effect on the loading on the market excess return either declines thereafter or loses statistical significance. Gains in the stock market and the overall economy provide one explanation for the time path, since improvement in the solvency position of defined-benefit pension funds and their sponsors would counteract any deleterious effect of low interest rates on reaching for yield.

An important clarification is that nothing in the regression evidence distinguishes the effects of low interest rates from other aspects of the post2009 environment. For example, bankruptcy risk rises during recessions.

38. Intuitively, if there is positive serial correlation in the error term, then a fund that does poorly one year resulting in poor funding status will also do poorly the next, biasing down $\gamma_{t}$, and vice versa, if the serial correlation is negative. Inclusion of the fund fixed effect $\alpha_{i}$ may exacerbate the identification problem for the same reason panel data models cannot include both a fixed effect and lagged dependent variable. However, results remain qualitatively unchanged with the fixed effect removed. 
Because of limited liability, higher bankruptcy risk may also lead plans to engage in higher risk taking.

\section{Conclusion}

The paper has investigated the effects of unconventional monetary policy on financial institutions. Using high-frequency event studies, I find the introduction of unconventional policy in the winter of 2008-09 had a strong, stabilizing impact on banks and especially on life insurance companies, consistent with the positive effects on legacy asset prices and future business dominating any impulse for additional risk taking. The positive effects on life insurers, in particular, suggest a recapitalizing channel of monetary policy. The interaction of low nominal interest rates and administrative costs led money market funds to waive fees, producing an incentive to reach for higher returns to reduce waivers. I find evidence of money market funds reaching for yield in 2009-11, but not thereafter. Private defined-benefit pension funds with worse funding status or shorter liability duration also seem to have reached for higher returns beginning in 2009, but again such behavior mostly dissipated by 2012. In sum, unconventional monetary policy helped to stabilize some sectors and provoked modest additional risk taking in others. I do not find evidence that the riskiness of the financial institutions studied fomented a trade-off between expansionary policy and financial stability at the end of 2013.

I conclude here with some caveats and directions for further research. First, if unconventional policy has benefited life insurers and banks, then withdrawing monetary stimulus may have a detrimental impact. The 2013 taper event dates provide some reassurance; tightening adversely affected life insurers and banks, but the magnitudes do not appear especially large or asymmetric. A second concern is that unconventional monetary policy could foster financial instability or a mispricing of risk outside of the institutions studied. Feroli and others (2014) discuss how a small tightening of monetary policy could generate a coordinated withdrawal by asset fund managers from riskier assets, resulting in an increase in risk premia. This mechanism resembles a metaphor offered by Jeremy Stein (2013b), namely that the Federal Reserve could have a looser grip on the steering wheel than it would prefer. Public pension funds, hedge funds, and households also merit scrutiny for possibly engaging in reaching for yield behavior. In the international realm, some emerging-market economies appear vulnerable to the effects of tightening, and history teaches that instability from emerging markets can have global effects. Finally, money market funds' 
practice of reaching for yield could again become a vulnerability if credit spreads widen.

ACKNOWLED G M ENTS I am grateful to Markus Brunnermeier, Joshua Hausman, Nellie Liang, Atif Mian, Hyun Song Shin, and David Sraer, to seminar participants at Arizona State, Duke, and Princeton universities, to participants at the Spring 2014 Brookings Panel on Economic Activity, and especially to the volume editors and my discussants for many useful conversations and comments. Matthieu Gomez provided superb research assistance. This work was completed while I was visiting the Julis-Rabinowitz Center at Princeton University. I also acknowledge financial support from the Brookings Institution. 


\section{References}

Adrian, Tobias, and Hyun Song Shin. 2012. "Financial Intermediaries and Monetary Economics." In Handbook of Monetary Economics (vol. 3), edited by Benjamin M. Friedman and Michael Woodford. Elsevier.

American Council of Life Insurers. 2013. 2013 Life Insurers Fact Book. Washington.

Angrist, Joshua, and Jorn-Steffen Pischke. 2009. Mostly Harmless Econometrics. Princeton University Press.

Becker, Bo, and Victoria Ivashina. Forthcoming. "Reaching for Yield in the Bond Market." Journal of Finance.

Bernanke, Ben. 2013. "Testimony of Chairman Ben S. Bernanke before the Joint Economic Committee, U.S. Congress, Washington, D.C., May 22, 2013.” Posted at the website of the Federal Reserve at http://www.federalreserve.gov/ newsevents/testimony/bernanke20130522a.htm.

Bernanke, Ben, and Alan S. Blinder. 1992. "The Federal Funds Rate and the Channels of Monetary Transmission.” American Economic Review 82, no. 4: 901-21.

Borio, Claudio, and Haibin Zhu. 2012. "Capital Regulation, Risk-Taking and Monetary Policy: A Missing Link in the Transmission Mechanism?" Journal of Financial Stability 8, no. 4: 236-51.

Brunnermeier, Markus K., and Yuliy Sannikov. 2011. "The I Theory of Money." Working Paper. Princeton University (http://scholar.princeton.edu/markus/ files/i_theory.pdf).

_ 2014. "A Macroeconomic Model with a Financial Sector." American Economic Review 104, no. 2: 379-421.

Campbell, Jeffrey, Charles Evans, Jonas Fisher, and Alejandro Justiniano. 2012. "Macroeconomic Effects of Federal Reserve Forward Guidance." Brookings Papers on Economic Activity, Spring: 1-80.

Chodorow-Reich, Gabriel. 2014. "The Employment Effects of Credit Market Disruptions: Firm-Level Evidence from the 2008-09 Financial Crisis." Quarterly Journal of Economics 129, no. 1: 1-59.

Christoffersen, Susan E. K., and David K. Musto. 2002. "Demand Curves and the Pricing of Money Management." Review of Financial Studies 15, no. 5: 1499-1524.

Dell'Ariccia, Giovanni, Luc Laeven, and Robert Marquez. 2014. "Real Interest Rates, Leverage, and Bank Risk-Taking." Journal of Economic Theory 149: 65-99.

Drechsler, Itamar, Alexi Savov, and Philipp Schnabl. 2013. “A Model of Monetary Policy and Risk Premia." Unpublished manuscript.

English, William B., Skander J. Van den Heuvel, and Egon Zakrajsek. 2012. "Interest Rate Risk and Bank Equity Valuations." Finance and Economics Discussion Series 2012-26. Washington: Board of Governors of the Federal Reserve System. 
Feroli, Michael, Anil Kashyap, Kermit Schoenholtz, and Hyun Song Shin. 2014. "Market Tantrums and Monetary Policy." Draft prepared for the 2014 U.S. Monetary Policy Forum (http://research.chicagobooth.edu/igm/usmpf/2014file.aspx).

Fisher, Richard. 2014. "Beer Goggles, Monetary Camels, the Eye of the Needle and the First Law of Holes." Remarks presented to the National Association of Corporate Directors, Dallas, January 14 (http://www.dallasfed.org/assets/ documents/news/speeches/fisher/2014/fs140114.pdf)

Gagnon, Joseph, Matthew Raskin, Julie Remache, and Brian Sack. 2010. "LargeScale Asset Purchases by the Federal Reserve: Did They Work?" Staff report no. 441. New York: Federal Reserve Bank of New York.

Gertler, Mark, and Simon Gilchrist. 1994. "Monetary Policy, Business Cycles, and the Behavior of Small Manufacturing Firms." Quarterly Journal of Economics 109, no. 2: 309-40.

Gilchrist, Simon, and Egon Zakrajsek. 2012. "Credit Spreads and Business Cycle Fluctuations." American Economic Review 102, no. 4: 1692-1720.

—. 2013. "The Impact of the Federal Reserve's Large-Scale Asset Purchase Programs on Corporate Credit Risk.” Working Paper no. 19337 (Cambridge, Mass.: National Bureau of Economic Research).

Hanson, Samuel, and Jeremy Stein. 2012. "Monetary Policy and Long-Term Real Rates.” Working Paper (Washington, D.C.: Federal Reserve Board).

Harrington, Shannon, and Andrew Frye. 2009. "Lincoln Leads Increase in Insurer Credit Swaps after Downgrade." Bloomberg.com, March (http://www.bloomberg. com/apps/news?pid=newsarchive\&sid=aurl7R1EMtEA).

Hattori, Masazumi, Andreas Schrimpf, and Vladyslav Sushko. 2013. "The Response of Tail Risk Perceptions to Unconventional Monetary Policy." Working Paper no 425 (Basel: Bank for International Settlements).

He, Zhiguo, and Arvind Krishnamurthy. 2013. "Intermediary Asset Pricing." American Economic Review 103, no. 2: 732-70.

International Monetary Fund. 2013. "Global Financial and Stability Report." Technical report. April. Washington, D.C.

Investment Company Institute. 2011. "Pricing of U.S. Money Market Funds." Washington (http://www.ici.org/pdf/ppr_11_mmf_pricing.pdf).

Jensen, Michael C., and William H. Meckling. 1976. "Theory of the Firm: Managerial Behavior, Agency Costs and Ownership Structure.” Journal of Financial Economics 3, no. 4: 305-60.

Kacperczyk, Marcin, and Philipp Schnabl. 2013. "How Safe Are Money Market Funds?" Quarterly Journal of Economics 128, no. 3: 1073-1122.

Kashyap, Anil, and Jeremy Stein. 2000. "What Do a Million Observations on Banks Say about the Transmission of Monetary Policy?" American Economic Review 90, no. 3: 407-28.

Kiley, Michael. 2013. "Monetary Policy Statements, Treasury Yields, and Private Yields: Before and After the Zero Lower Bound." Federal Reserve Finance and Economics Discussion Series 2013-16. Washington, D.C.: Federal Reserve Board. 
Koijen, Ralph, and Motohiro Yogo. 2013. "The Cost of Financial Frictions for Life Insurers." Fama-Miller Working Paper and Chicago Booth Research Paper no. 12-30 (available at SSRN: http://ssrn.com/abstract=2031993).

Krishnamurthy, Arvind, and Annette Vissing-Jorgensen. 2011. "The Effects of Quantitative Easing on Interest Rates: Channels and Implications for Policy." Brookings Papers on Economic Activity, Fall: 215-87.

Lucas, Deborah, and Stephen Zeldes. 2006. "Valuing and Hedging Defined Benefit Obligations.” Working Paper. Columbia Graduate School of Business (http:// www0.gsb.columbia.edu/mygsb/faculty/research/pubfiles/2382/lucas_zeldes_ hedgepaper6d.pdf).

McCabe, Patrick. 2010. "The Cross-Section of Money Market Fund Risks and Financial Crises." Finance and Discussion Paper no. 51 (Washington, D.C.: Federal Reserve Board).

McKinsey Global Institute. 2013. "QE and Ultra-Low Interest Rates.” Technical report. November (http://www.mckinsey.com/insights/economic_studies/qe_and_ ultra_low_interest_rates_distributional_effects_and_risks).

Merton, Robert. 1974. "On the Pricing of Corporate Debt: The Risk Structure of Interest Rates.” Journal of Finance 29, no. 2: 449-70.

MetLife, Inc. 2010. "Annual Report” (http://phx.corporate-ir.net/External.File? item=UGFyZW50SUQ9NDE5MDc1fENoaWxkSUQ9NDMyMjQzfFR5cGU9 $\mathrm{MQ}==\& \mathrm{t}=1)$.

Moody's Investors Services. 2012. "U.S. Life Insurers Vulnerable to Protracted Low Interest Rates." Technical report. December (https://www.moodys.com/ research/Moodys-US-life-insurers-vulnerable-to-protracted-low-interest-ratesPR_262541).

Nakamura, Emi, and Jon Steinsson. 2013. "High Frequency Identification of Monetary Non-neutrality." Unpublished manuscript, Columbia University. (http://www.columbia.edu/ en2198/papers/realrate.pdf).

Rajan, Raghuram. 2005. "Has Financial Development Made the World Riskier?" In Proceedings of the Jackson Hole Conference. Kansas City: Federal Reserve Bank of Kansas City.

Rauh, Joshua D. 2009. "Risk Shifting versus Risk Management: Investment Policy in Corporate Pension Plans." Review of Financial Studies 22, no. 7: 2687-33.

Roache, Shaun, and Marina Rousset. 2013. "Unconventional Monetary Policy and Asset Price Risk.” Working Paper no. 13/190. International Monetary Fund, Washington, D.C.

Securities and Exchange Commission. 2013. "Money Market Fund Reform; Amendments to Form PF." Release No. 33-9408, IA-3616; IC-30551; File No. S7-03-13. Washington, D.C.

Shleifer, Andrei, and Robert Vishny. 2011. "Fire Sales in Finance and Macroeconomics." Journal of Economic Perspectives 25, no. 1: 29-48.

Stein, Jeremy. 2012. "Monetary Policy as Financial Stability Regulation." Quarterly Journal of Economics 127, no. 1: 57-95. 
2013a. "Overheating in Credit Markets: Origins, Measurement, and Policy Responses." Remarks presented at the research symposium, "Restoring Household Financial Stability after the Great Recession: Why Household Balance Sheets Matter," sponsored by the Federal Reserve Bank of St. Louis, St. Louis, February 7.

. 2013b. "Yield-Oriented Investors and the Monetary Transmission Mechanism." Remarks presented at the Center for Financial Studies symposium, "Banking, Liquidity and Monetary Policy," Frankfurt, Germany, September 26. Werning, Iván. 2012. "Managing a Liquidity Trap: Monetary and Fiscal Policy." Unpublished Working Paper (http://economics.mit.edu/files/7558).

Wright, Jonathan H. 2012. "What Does Monetary Policy Do to Long-Term Interest Rates at the Zero Lower Bound?" Economic Journal 122, no. 564: F447-F466. 


\section{Comments and Discussion}

\section{COMMENT BY}

DEBORAH LUCAS How did unconventional monetary policies influence financial institutions' propensities to take investment risk, and what were their effects on the health of financial institutions more broadly? Those questions are of first-order importance for policy evaluation, and their answers continue to be a topic of intense debate. Gabriel ChodorowReich explores the hypothesis that while unconventional policies may have been helpful to the overall economy, they also might have induced financial institutions to take excessive risk through "reaching for yield." He interprets the empirical findings as supporting the conclusion that those policies had salutary effects on the solvency of life insurers and banks, with little increase in risk-taking except by some money market mutual funds and pension funds during a relatively short period.

My discussion offers a somewhat contrarian perspective on several counts: what theory predicts about the likely effects of the policies on aggregate investment risk-taking; whether the event studies are revealing about such effects; and what should be deemed a policy success. Nevertheless, the paper represents a significant contribution to the conversation about these important issues and deserves a careful read by any researcher or policymaker working in this area.

THEORETICAL CONSIDERATIONS. Chodorow-Reich's analysis begins by laying out four possible consequences of unconventional monetary policies that lower long-term nominal yields. They are (i) that real spending on risky projects changes through a hurdle rate effect; (ii) that the value of legacy assets rises; (iii) that optimal leverage changes; and (iv) that the policies may prompt reaching for yield, which is defined as an increase in risk taking beyond what the end holders of the risk would prefer. 
A conclusion of the theoretical portion of Chodorow-Reich's analysis seems to be that spending on risky projects is likely to increase. However, in general (and even in the stylized model used in the paper to frame the issues), the effect of lower yields on risk taking is theoretically indeterminate. Theory does suggest that additional low-risk projects that previously were deemed unprofitable will be undertaken via a hurdle rate effect and that the value of low-risk legacy assets will rise. However, whether in equilibrium the aggregate investment risk rises or falls will depend critically on the properties of the posited utility function and other structure assumptionsso risk tolerance could rise or fall.

The likely effects of unconventional monetary policies on optimal leverage and on the incentives to reach for yield are even less obvious. The predicted effects mentioned are model-specific and are highly sensitive to the types and structure of market imperfections assumed. For example, it is well established theoretically that under the assumption that managers are risk-averse and that their compensation depends on project success, they will tend to make less risky investments than desired by the end holders of the investment risk.

In sum, while there are plausible scenarios under which unconventional monetary policies could cause greater risk taking through riskier project choices or higher leverage ratios, there are other defensible models that cut the other way. Theory offers relatively little guidance on what we should expect to see in the data.

WHAT CAN BE LEARNED FROM EVENT STUDIES? How unconventional monetary policy affected the financial condition and risk taking propensities of banks and life insurers is addressed by Chodorow-Reich empirically, through event studies of the price effects on credit default swaps (CDSs), yields, and stock prices in short windows around the time of unanticipated policy announcements. Although there are precedents for using event studies to identify macroeconomic announcement effects, it is important to understand their methodological limitations.

The first limitation is temporal. The methodology reveals how markets react to an announcement in the first minutes or hours after it is made, but it does not shed light on whether those effects are persistent or transitory. The complexity of effects associated with monetary policy actions, and their changing impact over time with economic conditions, suggest that the measured effects may be transitory and therefore unreliable measures of the longer-term consequences of monetary policy actions. By contrast, more traditional uses of event studies have the potential to avoid that criticism because they consider a much larger sample of information events. In such cases, it is possible to verify the persistence of announcement effects by exam- 
ining price behavior in the days or months following the announcements. For example, a classic event study in corporate finance looked at whether negative recommendations in the Wall Street Journal caused stock prices to fall and found that they did. Lining up the effects of many events revealed a negative abnormal return on the day of the recommendation and no further abnormal returns over the subsequent 20 days. In the case of unconventional monetary policy, however, the number of relevant events is too small for that strategy of studying post-announcement average returns to be feasible.

Caution is also indicated in interpreting reductions in CDS premiums and bond yields as primarily due to the expectation that financial institutions will actively engage in less risk taking, as is done here. In fact, those quantities are affected by several factors that may be largely unrelated to the choices of financial institutions. Conceptually, CDS premiums are the sum of the expected loss rate from defaults on the underlying bond, a market risk premium that compensates investors for the undiversifiable risk associated with default, and a price adjustment for the counterparty risk associated with the CDS contract itself. During the financial crisis and in its aftermath, the components that were associated with the market risk premium (which are always large) and counterparty risk were thought to significantly increase and become more volatile relative to normal times. Similarly, bond yields contain components related to the market risk premium and to the liquidity of the underlying bond, both of which became more important and more volatile during the crisis.

In fact, the event studies only find a significant effect of unconventional monetary policy on CDS premiums during the period of the first round of quantitative easing $(\mathrm{QE} 1)$, when factors such as changes in market risk premiums and counterparty risk were arguably the most important. The changes in yield spread were generally insignificant. A further confounding factor for interpreting the effects of QE1 is that the policy took place against the backdrop of massive fiscal and other Federal Reserve policies aimed at stemming the financial crisis. Those actions included the passage of the Housing and Economic Recovery Act in September 2008, which rescued Fannie Mae and Freddie Mac by providing an explicit government backing; the $\$ 700$ billion Troubled Asset Relief Program (TARP), which recapitalized large bank holding companies, the insurance company AIG, and automobile manufacturers; and the truly unconventional policies of the Federal Reserve (in combination with the Treasury) to provide liquidity facilities such as the CPFF, TALF, and the Maiden Lane transactions. In fact an enormous and rapid infusion of funds from TARP and the take-up of Federal Reserve liquidity facilities in the period coincided with QE1. The 
coincidence of QE1 with those other massive financial and fiscal policy interventions suggests that the broad inferences about the causal effects of unconventional policy suggested in the paper are ill-advised. Furthermore, later rounds of quantitative easing coincided with the tapering off of other financial and fiscal policies, suggesting that the differing effects of monetary policy on investor expectations over time may be attributable in part to changes in its interactions with other policies.

Chodorow-Reich presents new and persuasive evidence that, as would be expected, money market mutual funds tended to change their investment policies when yields fell to levels below what was needed to cover expenses. However, to understand the behavior of money market funds over that period, an important part of the story that one must consider is the Federal Reserve's special liquidity facilities. The provision of those facilities restored liquidity to riskier short-term assets, and an increase in money market fund purchases of such securities was in fact the intended purpose of their introduction. The subsequent decline in money market fund risk taking may be partially attributable to new SEC rules issued in 2010 designed to curtail that behavior.

IS REACHING FOR YIELD A POLICY CONCERN OR A DESIGN FEATURE? The presumption behind the analysis, namely that increased risk taking by financial institutions would be an adverse consequence of unconventional monetary policies, was surprising to me. Whereas that concern has been expressed regarding past monetary policies and the future consequences of more recent ones, arguably the intent of quantitative easing was to increase risk tolerance and thereby increase lending and growth.

Many commentators have pointed to the low-interest-rate policies of the precrisis era as precipitating the growth of subprime lending and fueling the housing price bubble, whose collapse triggered the financial crisis and subsequent Great Recession. However, the Federal Reserve undertook its unconventional monetary policies during a period of persistently high unemployment and low economic growth. A serious concern among policymakers was that lenders, worried about rebuilding capital and heightened uncertainty, were exhibiting higher risk aversion than was socially optimally. Furthermore, the massive purchases of agency debt and MBSs were explicitly intended to offset the pullback of investors from the risks of the housing market. Viewed in that light, finding a causal link between quantitative easing and reaching for yield could be interpreted as evidence of policy success rather than an unfortunate side effect. This is especially true for insurance companies and bank holding companies, which are important providers of risk capital to the real economy. It is to some extent also true 
for money market mutual funds, which are major providers of capital to firms through the commercial paper market.

In this vein, an alternative narrative has been suggested, which is at least partly supported by the findings here, in which minimal increases in risk taking are a consequence of unconventional monetary policies. It is argued that those policies have inadvertently hurt the economy by closing down the normal channels of bank risk taking. That is, banks normally profit from the term premium in the yield curve because the duration of their assets exceeds that of their liabilities. When monetary policy flattens the curve, banks have a reduced incentive to lend at the longer maturities that firms prefer to borrow at. This alternative viewpoint argues that traditional bank lending, and hence risk taking by financial institutions, will finally recover to more normal levels only when the yield curve is allowed to steepen.

\section{COMMENT BY}

ANNETTE VISSING-JORGENSEN The question of whether unconventional monetary policy (UMP) could generate undesirable side effects is an issue central to current policymaking. Gabriel Chodorow-Reich's paper is a useful contribution to this debate and provides several pieces of comforting evidence indicating that UMP (quantitative easing and forward guidance) led to safer banks and life insurance companies. For both money market funds and pension funds there is evidence that funds in a worse financial position did some reaching for yield (relative to other funds), but this occurred mainly in 2009 and only to an economically small extent. I would like to raise four issues related to the paper.

IS AN EVENT STUDY OF STOCK PRICES AND CDS RATES SUFFICIENT? ChodorowReich conducts an event study of life insurer and bank holding company stock returns, CDS changes, and bond yield changes on 14 days with UMP announcements. He finds that dates with expansionary policy announcements tend to have positive stock returns and negative CDS changes and concludes that UMP made the financial sector safer. This conclusion seems correct in that a higher stock price combined with a lower CDS rate indicates that a firm is further from default.

It is important, however, to be precise about exactly what we are worried that UMP could cause: (1) a meltdown somewhere in the financial sector with large systemic effects; (2) inefficient investment, with some risky activities getting financed only because of artificially low risk premiums; (3) inflated asset prices and risk of price crashes, with ensuing wealth effects. 
The analysis conducted for life insurers and banks is useful for addressing concern 1, although it is likely that some of the CDS rate reductions are due to reduced risk premiums as opposed to a reduced probability of default. The analysis is less useful for addressing concerns 2 and 3, because it does not inform us about which channels were behind the changes in stock prices and CDS rates. The problem is that one cannot infer whether a financial institution is increasing (expected to increase, to be precise) the risk of its assets by reaching for yield or adding leverage from looking at its stock price and CDS rate changes. These variables summarize the overall effect of the policy announcement on the financial health of the institution, but this is the net effect of (i) the impact of UMP on the financial institution's stock price and CDS rate if it made no active choices to change its risk (let us call that the "passive impact"); and (ii) the impact of UMP on the financial institution's stock price and CDS rate due to the financial institution's decisionmaking (call that the "active impact").

One cannot unambiguously sign the passive impact. Consider banks first. Banks tend to hold medium- and long-term assets and to be funded mainly with short-term liabilities. From my figure 1 it is clear that UMP mainly affected long-term rates. Therefore, for a financial institution with medium/ long (fixed-rate) assets and short-term liabilities, UMP must have led to an equity value increase by a standard-duration argument (several recent papers document that banks do not hedge this duration risk; for example, see Begenau, Piazzesi, and Schneider 2013). Add to that the positive effect on equity from UMP leading to improvements in repayment rates on bank loans and increased household/firm demand for borrowing. On the other hand, a flatter yield curve makes each unit of future maturity-transforming business less profitable, leaving an ambiguous impact of UMP on a bank's equity if the bank made no active choices to change its risk. ${ }^{1}$

However, suppose the passive impact is substantial and positive. Then the passive impact will increase equity values and reduce CDS rates. In Chodorow-Reich's table 2 for banks, CDS rates drop by a tiny amount (a marginally significant 3.3 basis points according to Chodorow-Reich's standard errors) on the main two event dates for the first round of quantitative easing $(\mathrm{QE} 1)$. This could be the net effect of the passive impact lowering risk and the active impact adding risk, each affecting CDS rates

1. English, Van den Heuvel, and Zakrajsek (2012) discuss the many channels for interest rates to affect bank equity values. Using data for 1997-2007 they assess the impact of monetary policy-induced level and slope changes on bank equity and find results consistent with those of the present paper; however, as in the present paper, their results show the net effect of policy and do not speak directly to banks' active choices to add or subtract risk. 
Figure 1. Decomposing Changes in the 5-Year Treasury Yield on the 14 Event Dates ${ }^{\mathrm{a}}$

Daily yield change, bps

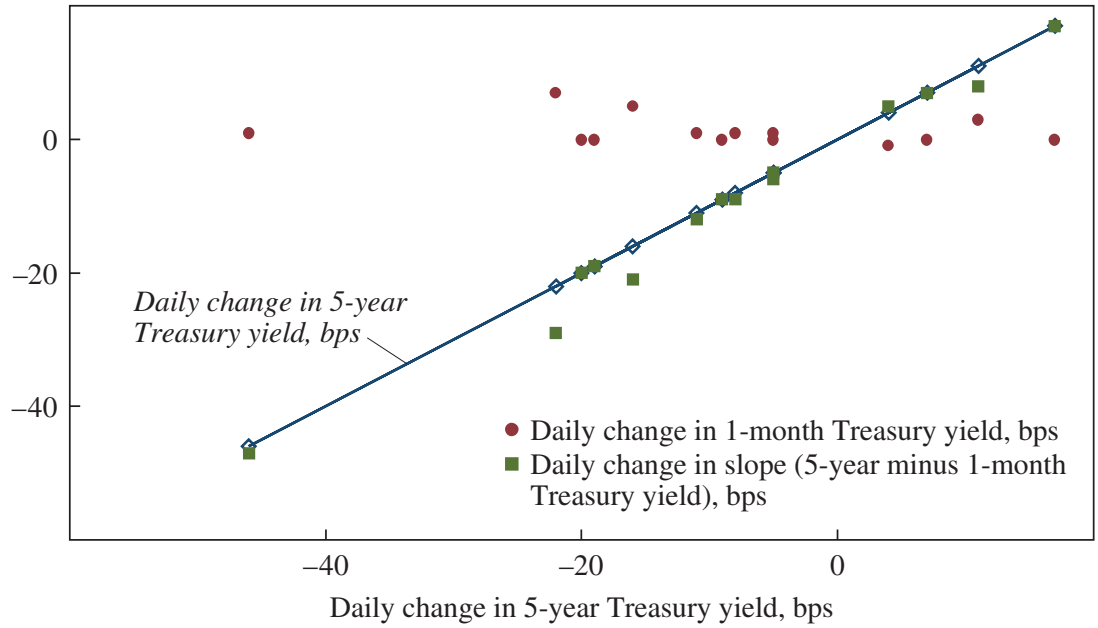

Source: Treasury yields from the Federal Reserve Bank of St. Louis.

a. Event dates are from table 2 in Chodorow-Reich's paper in this volume.

with opposite signs. A similar argument applies to life insurers. While these institutions tend to have longer liabilities than assets (leading to an equity loss from a drop in long rates), they could still be experiencing a positive passive impact if UMP reduced default rates on mortgage-related and corporate investments or if UMP increased insurance demand.

Therefore, observing higher stock prices and lower CDS does not allow one to rule out that reaching for yield behavior could have occurred. It might not have occurred, but the results presented do not rule it out and thus do not alleviate concerns 2 and 3 above relating to inefficient investment and inflated asset prices. It is also worth noting that, in prior work, IMF (2013) conducted a similar event study of the impact of recent monetary policy on bank stock returns. They regress stock returns on changes in 1-year-ahead 3-month futures rates (which given my figure 1 may not be ideal for fully capturing UMP). From this they find no significant effects of policy on U.S. bank stock returns either before or after July 2007, but find that expansionary monetary policy led to significantly negative bank stock returns in the euro area and the United Kingdom.

To determine whether banks or life insurers have made choices to increase their asset risk, and thus start addressing concerns 2 and 3, it would have been useful to study the asset composition and leverage choices of 
banks and life insurers. An alternative approach would be to focus not on particular types of institutions but on particular types of investments. This is particularly useful for addressing concerns 2 and 3 above. Jeremy Stein (2013) follows this approach and looks at the issuance of various types of corporate credit (high-yield bonds, syndicated leveraged loans, paymentin-kind bonds, covenant-lite loans, and dividend-recapitalization loans) and flows into high-yield mutual funds, high-yield ETFs, and the size of agency REITs. Stein's results appear to raise more concerns than the present paper's findings. Similarly, many have commented on the risks to investors and to emerging-market economies from large flows to emerging-market equities and bonds (see, for example, IMF 2014 and FSOC 2014). While large issuance of high-yield bonds does not prove that UMP has led to financing of high-risk activities that would not be financed in the absence of UMP, it does raise this possibility. Of course, that does not necessarily mean that such activities are undesirable, since some amount of additional risk taking was likely one of the intended channels for UMP, but it leaves one feeling less calm than Chodorow-Reich's event study analysis, especially regarding concerns 2 and 3 above.

THE CROSS SECTION OF MONEY MARKET AND PENSION FUNDS. While the analysis of banks and life insurers does not address which institutional characteristics may drive the reaction to UMP of stock returns, CDS rates, and bond yields, the paper's analysis of money market funds and pension funds focuses on a cross-sectional identification. It was not clear from the paper why these different approaches were taken. I would have liked to understand both the average effect of UMP on a given institutional sector and the cross-sectional determinants of reactions to UMP within a given institutional sector.

In the cross-sectional approach, Chodorow-Reich conjectures that reaching-for-yield behavior is more likely among the less financially sound funds (money market funds with large expenses and poorly funded pension funds), and he tests whether such funds make different choices than more financially sound funds in a given time period. This is useful, in that the behavior of the more financially sound funds can serve as a benchmark.

He finds some, but not much, evidence of reaching for yield by money market funds and pension funds. For example, in the pension fund results the impact of a one-standard-deviation increase in benefits NPV/assets on a pension fund's stock market beta is $0.18 \times 0.33=0.06$ higher in 2009 than in 2006 based on the paper's table 7 and table 8 (column 3), with mixed results for the other years. The small effects are perhaps not surprising given prior work. Joshua Rauh (2009) showed that less well-funded 
pension plans take less risk than better funded ones (this is confirmed in the paper's table 8 by the negative coefficient on the first variable). This finding contrasts with the findings for mutual funds, for which Judith Chevalier and Glenn Ellison (1997) found that mutual funds that have underperformed the market in the first 9 months of a given year have an incentive (via fund flows) to increase idiosyncratic risk in the remainder of the year, and do in fact do so.

To explain his findings, Rauh (2009) notes that while poor funding status may lead to a risk-shifting incentive (along the lines of Jensen and Meckling 1976), it also leads to a risk-management incentive. The riskmanagement incentive stems from the fact that a firm sponsoring a less well-funded plan is likely to be more financially constrained. Therefore, any adverse shocks are particularly painful, since they may lead the firm to have to forgo profitable investment projects in the future should the firm survive and have to make even larger contributions to its pension plan due to unsuccessful risk taking. Rauh's findings have a similar flavor to those from the hedge fund industry. Itamar Drechsler (2014) summarizes empirical work on hedge funds that shows that funds that are below their "highwater mark" (the point at which they start earning performance fees) tend to reduce their risk, not increase it. Drechsler provides a theoretical framework for understanding which trade-offs drive risk choice.

Given Rauh's finding that the risk-management incentive overcomes the risk-shifting incentive for more poorly funded pension funds, one would not expect less-well-funded plans to react substantially more aggressively to deterioration in investment opportunities due to UMP than better-funded plans. Perhaps it is not surprising that Chodorow-Reich only finds small reachingfor-yield effects and finds them only for some part of the UMP period. ${ }^{2}$

While the paper's results on the cross section of pension funds and money market funds are a very useful contribution, it would have been equally important to study how the behavior of the average pension fund and the average money market fund changes over time. This could be done by documenting the evolution of the portfolio weights for the typical fund over time to assess duration, credit risk, illiquidity, and so on. (This is a different exercise from the one used in the paper's figure 13, which shows that over time the price incentives to reach for yield have compressed dramatically.)

2. In the money market fund context, funds with higher incurred expenses may similarly have a higher incentive to risk-manage. This will depend on which funds are inherently (that is, off the zero lower bound) more profitable and thus have a stronger incentive to try to stay in business. 
Relatedly, the money market fund sector has shrunk by about 30 percent since its peak in terms of both assets under management (which are down by about 1 trillion dollars since the end of 2008) and the number of funds (see the paper's table 5). This is likely a good thing for financial stability, since it indicates that many funds were unwilling or unable to reach sufficiently for yield to stay in business, but one cannot fully assess this without knowing where the money went that left the money market fund sector.

IS THE ANALYSIS LOOKING IN ALL THE RIGHT PLACES? My table 1 provides a summary of the size of the U.S. financial industry, by sector, using data from the Financial Accounts (formerly the Flow of Funds Accounts). The sectors studied in the present paper-life insurers, banks, private defined-benefit pension plans, and money market funds-constitute less than one-third of what the Financial Accounts defines as financial business (I summed the rows for table L.110, L.115, L.117.b, and L.120 and divided by the total). It is unclear from the paper why it focuses on these four sectors. Are these the most likely places to see increased risk taking in response to UMP? Are they considered more systemic in that losses in these four parts would have worse effects on the overall economy than elsewhere? Are they intended to be representative of the rest of the financial sector? Can effects be identified more clearly in these sectors?

Among the parts of the financial sector not studied, an emerging set of facts suggests that risk taking has increased in recent years, possibly in response to UMP. Some examples follow.

The Federal Reserve is of course taking on large risks, given the large expansion and increased duration of its balance sheet. There are two risks to the Fed. First, if the interest paid on reserves is increased sufficiently fast, the Fed may pay more interest on reserves than it earns from its holdings. Second, even with a buy-and-hold policy, market value capital losses may increase political pressure on the Fed's independence. David Greenlaw, James Hamilton, Peter Hooper, and Frederic Mishkin (2013) present an assessment of these risks.

Moving down the list, FSOC (2014) documents increased asset maturity for credit unions and warns about reaching for yield in that sector. Several papers focus on public pension funds. These have more incentive to reach for yield than private pension funds because of accounting rules that allow public pension funds to change the discount rate on their liabilities as a function of the expected return on their assets. IMF (2013) documents increased allocations to risky assets (equities and alternative investments) by the weakest 10 percent of U.S. public pension funds. 
Table 1. Size of the U.S. Financial Industry: Financial Assets as of the End of 2013 (billions of dollars) ${ }^{\mathrm{a}}$

Total financial business

$\underline{82,199}$

L.108 Monetary authority

L.110 U.S.-chartered depository institutions, excluding credit unions

12,803

L.111 Foreign banking offices in U.S.

2,037

L.112 Banks in U.S.-affiliated areas

L.113 Credit unions

L.114 Property-casualty insurance companies

L.115 Life insurance companies

L.117.b Private pension funds, defined benefit

L.117.c Private pension funds, defined contribution $\quad 4,905$

L.118 State and local government employee retirement funds $\quad 4,846$

L.119 Federal government employee retirement funds 3,531

$\begin{array}{lr}\text { L.120 Money market mutual funds } & 2,678\end{array}$

$\begin{array}{lr}\text { L.121 Mutual funds } & 11,545\end{array}$

L.122 Closed-end and exchange-traded funds $\quad 284$

$\begin{array}{ll}\text { L.123 GSEs } & 6,361\end{array}$

L.124 Agency- and GSE-backed mortgage pools $\quad 1,569$

$\begin{array}{ll}\text { L.125 Issuers of asset-backed securities } & 1,615\end{array}$

$\begin{array}{lr}\text { L.126 Finance companies } & 1,473\end{array}$

L.127 Real estate investment trusts $\quad 507$

$\begin{array}{lr}\text { L.128 Security brokers and dealers } & 3,408\end{array}$

$\begin{array}{lr}\text { L.129 Holding companies } & 4,276 \\ & \end{array}$

$\begin{array}{lr}\text { L.130 Funding corporations } & 2,023\end{array}$

\begin{tabular}{lr} 
Hedge funds (data from FSOC (2014)) $\quad 2,600$ \\
\hline
\end{tabular}

Source: Financial Accounts of the United States, version of June 5, 2014.

a. Number labels in front of sector names refer to table numbers in the Financial Accounts.

Note that my total differs from that in Financial Accounts table L.107 because the subcomponents do not sum to the total provided in that table and because I add the size of the hedge fund sector based on data from FSOC (2014).

Aleksandar Andonov, Rob Bauer, and Martijn Cremers (2014) study public and private pension funds in the United States, Canada, and Europe and show that only U.S. public pension funds increase their allocation to risky assets in response to declining government bond yields. Within the mutual fund sector, the increase in allocations to high-yield funds and emerging-market funds has been substantial. Based on data from the CRSP mutual fund database, allocations to high-yield funds have increased from around $\$ 164$ billion at the end of 2007 to about $\$ 386$ billion at the end of 2013. During the same period, allocations to emerging-market funds have increased from around $\$ 225$ billion to around $\$ 481$ billion. 
Many have observed that REITs have grown dramatically, but since REITs make money on maturity transformation and since my figure 1 showed that UMP has worked to reduce the slope of the yield curve, this growth likely cannot be blamed on the yield curve effects of UMP (but still remains a concern for financial stability). What about hedge funds? Andrew Patton and Tarun Ramadorai (2013), using data for 1994-2009, find that hedge funds increase their exposure to the stock market (likely through increased leverage) in response to lower borrowing costs, lower volatility, and higher funding liquidity. Using a short time series for 200409, Andrew Ang, Sergiy Gorovyy, and Gregory van Inwegen (2011) find that hedge fund leverage (assets to equity capital) was highest just before the start of the crisis and that it is decreasing in both the level and slope of the yield curve. This suggests that UMP may have increased hedge fund leverage. Consistent with that, hedge fund leverage is now (as of April 2014) back to its previous peak of 1.7 reached in $2007 .{ }^{3}$ I do not have a time series available to illustrate hedge fund leverage, but a related and widely followed measure of investor borrowing is the amount of margin debt in brokerage accounts (at NYSE member firms). These margin accounts are used by both hedge funds and retail investors. My figure 2 plots this series and shows a dramatic increase in margin debt over the post-crisis period. However, since leverage and margin debt are well known to correlate strongly with the level of the stock market (this is apparent from the timing of the peaks in figure 2) and since presumably not all of the recovery of the stock market is due to monetary policy, it is important not to ascribe the full increase in leverage in the hedge fund sector to monetary policy.

While it is hard to assess the quantitative importance of each of the risks mentioned here, the fact that risks show up in many places is concerning, and it suggests that the conclusions from the present paper may have been different had it focused on some of the other parts of the financial sector. It should also be noted that while the literature on reaching for yield tends to focus on distortions caused by delegated decisionmaking, if one is concerned with inflated asset prices any increases in risk taking by households are equally important. Harald Hau and Sandy Lai (2013) provide evidence, based on cross-country variation in real policy rates within the eurozone, that households reach for yield in response to low real interest rates induced by monetary policy.

3. See Tricia Wright and Blaise Robinson, "Hedge Funds' Leveraged Bets on Market Rally to Magnify Sell-offs," Reuters, April 14, 2014 (http://www.reuters.com/article/ 2014/04/04/us-hedgefunds-stocks-idUSBREA330YP20140404) 
Figure 2. Margin Debt, 1994-2014

Billions of dollars

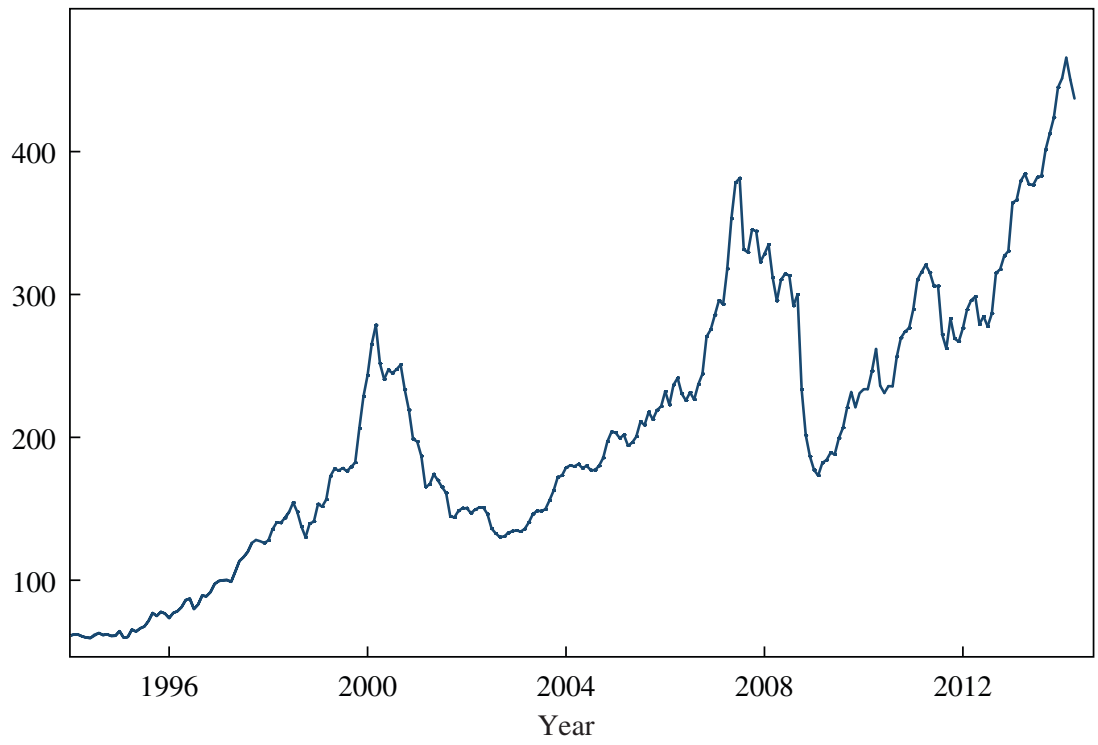

Source: New York Stock Exchange.

ASSESSING STATISTICAL SIGNIFICANCE IN THE EVENT STUDY. One of the main results of Chodorow-Reich's paper is the positive stock returns for life insurers and banks on event days with expansionary announcements (his table 2). According to the author's calculations, the vast majority of stock returns on event days are statistically significant at the 1 percent level. For the nonfinancials (the market, excluding life insurers and banks) the stock returns are statistically significant at the 1 percent level for all 14 event dates.

I do not think the way the standard errors are calculated is meaningful. The statistical significance is likely to be much overstated by the approach used. While stock returns on several of the event dates studied are significant even with what I consider a more reasonable approach, many are not, and I would like to discuss this issue to prevent the method used here from becoming widely used for monetary policy event studies.

The approach used is as follows. Consider life insurers on 12/16/2008 as an example. Chodorow-Reich has data for 13 publicly traded U.S. life 
insurers, and he runs a regression using one observation per firm of the stock return in a 20-minute event window on a constant, with 13 observations. The constant will estimate the common component $r_{t}$ in the decomposition $\mathrm{r}_{\mathrm{i}, \mathrm{t}}=\mathrm{r}_{\mathrm{t}}+\epsilon_{\mathrm{i}, \mathrm{t}}$. The OLS $t$ statistic of the estimated common component tells us whether the common component is statistically significantly different from zero, given the fact that the return we observe for each firm is also driven by a non-common component $\epsilon_{\mathrm{i}, \mathrm{r}}{ }^{4}$ What is wrong with that? Nothing, until you assume that the common component equals the impact of the monetary policy announcement. This important issue is only mentioned briefly in the paper's footnote 17: "Under the identifying assumption that no other aggregate shocks occur during the event window, the standard errors used here inform whether the monetary policy shock has a statistically systematic effect on the asset prices studied."

So, the approach assumes that there are no other common shocks during the 20-minute window and then uses the presence of non-common shocks to assess the statistical significance of the common component. Why does it make sense to assume that there are no other common shocks but that there are idiosyncratic shocks? If you allow for there being other common shocks during the 20-minute window, then even in the limit as the number of firms goes to infinity, you will estimate a common component that equals the monetary policy effect plus any other common component. In that case, to assess statistical significance of the monetary policy effect you would want to compare the size of the (overall) common component in this 20-minute window to the size of the common component in other 20-minute (nonevent) windows. For example, you could assess statistical significance using time-series regressions with dummies for policy windows (20-minute periods using data at the 20-minute frequency), as opposed to cross-sectional regressions. This would be similar to the approach used, for example, in Arvind Krishnamurthy and Annette Vissing-Jorgensen (2011) on daily data.

Perhaps a simpler way to say this is to consider the overall stock market. Suppose you observe that the overall market return is 0.5 percent in a given

4. Note that since the approach relies on having a cross section of observations for a given event period, it cannot be used to assess statistical significance for changes in the Treasury yield or CDX index included in the table. Thus, as I understand the table, the lack of significance markers for those columns do not mean that none of the changes for those variables are significant but that statistical significance was not assessed. 
policy event window. This is the common component with essentially no estimation error (given that any firm-specific shocks will average to very close to zero with thousands of firms in the market), and ChodorowReich's cross-sectional approach would give you a very large $t$ statistic. If you assume that this common component is due to the policy, then yes, you can be very sure the policy effect is significant. But that is an assumption, not a result. To test whether this common component is likely to be driven mainly by policy, once you allow for the possibility that there is also nonpolicy news, you need to compare this period's return to returns in other periods. ${ }^{5}$

Ideally, you would thus run a time series regression using data at the 20-minute frequency with 14 dummies for the 14 event periods. Since processing several years of tick-by-tick price data for all U.S. firms is tedious, I will do the analysis using daily data to get a sense of how different the $t$ statistics from Chodorow-Reich's cross-sectional approach are from my suggested time-series approach. For simplicity, I will define life insurance companies as those with NAICS code 524113 (Chodorow-Reich instead uses a list of the largest life insurers by assets from an insurance industry fact book). To define bank holding companies, I follow Chodorow-Reich's approach and use a list provided by the New York Fed. ${ }^{6}$ My table 2 gives the results using data from 2008-13. For my proposed time-series approach, I simply use OLS standard errors, but one could consider adjusting for any heteroskedasticity and autocorrelation. Since Chodorow-Reich's analysis focuses on value-weighted returns, I use value-weighted time-series returns for my time-series approach and weight observations by market value for my assessment of his cross-sectional approach.

It is clear from the table that my (very standard) approach leads to much lower $t$ statistics. The main conclusion from Chodorow-Reich's stock return analysis remains, in that many (though substantially fewer) of my $t$ statistics indicate statistical significance. Nevertheless, it should be clear from the comparison of $t$ statistics across these two approaches that the

5. Of course, an alternative approach would be to assume that there are neither idiosyncratic shocks nor nonpolicy common shocks during the event period. In that case there is no need for standard errors: The object of interest, the effect of the policy on average across firms, would equal the average return. You would know the number you want with certainty, but this would be because you assumed nothing else happened during the 20-minute window.

6. The list is available at http://www.newyorkfed.org/research/banking_research/data/ crsp_20120930.csv. 


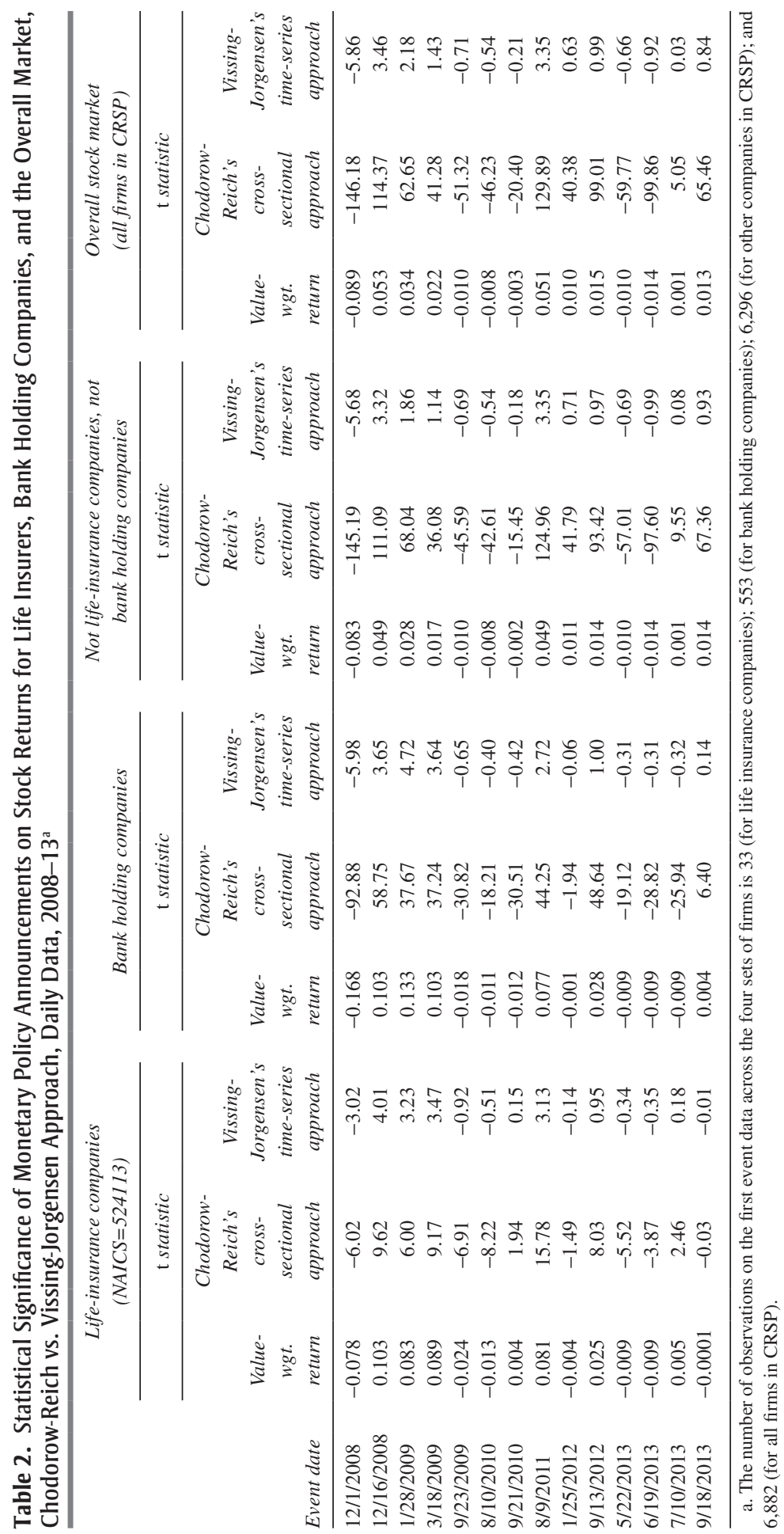


large $t$ statistics from Chodorow-Reich's approach come from an assumption (of no nonpolicy shocks during the event windows) as opposed to coming from a standard statistical analysis. Therefore, the cross-sectional approach seems a less attractive approach for future event studies.

\section{REFERENCES FOR THE VISSING-JORGENSEN COMMENT}

Andonov, Aleksandar, Rob Bauer, and Martijn Cremers. 2014. "Pension Fund Asset Allocation and Liability Discount Rates." Working Paper, Maastricht University.

Ang, Andrew, Sergiy Gorovyy, and Gregory B. van Inwegen. 2011. "Hedge Fund Leverage." Journal of Financial Economics 102, no. 1: 102-26.

Begenau, Juliane, Monika Piazzesi, and Martin Schneider. 2013. "Banks' Risk Exposures." Working Paper, Stanford University.

Chevalier, Judith, and Glenn Ellison. 1997. "Risk Taking by Mutual Funds as a Response to Incentives." Journal of Political Economy 105, no. 6: 1167-200.

Drechsler, Itamar. 2014. "Risk Choice under High-Water Marks." Review of Financial Studies 27, no. 7: 2052-96.

English, William B., Skander J. Van den Heuvel, and Egon Zakrajsek. 2012. "Interest Rate Risk and Bank Equity Valuations." Working Paper no. 2012-26, Finance and Economics Discussion Series (Washington: Federal Reserve Board).

Financial Stability Oversight Council (FSOC). 2014. 2014 Annual Report.

Greenlaw, David, James D. Hamilton, Peter Hooper, and Frederic S. Mishkin. 2013. "Crunch Time: Fiscal Crisis and the Role of Monetary Policy." U.S. Monetary Policy Forum, New York City, February 2013 (http://research.chicago booth.edu/igm/events/conferences/usmonetaryforum.aspx).

Hau, Harald, and Sandy Lai. 2013. "Asset Allocation and Monetary Policy: Evidence from the Eurozone.” Discussion Paper no. 9581. Center for Economic Policy Research, London.

International Monetary Fund (IMF). 2013. Global Financial Stability Report, April. Washington.

- 2014. Global Financial Stability Report, April. Washington.

Jensen, Michael C., and William H. Meckling. 1976. "Theory of the Firm: Managerial Behavior, Agency Costs and Ownership Structure." Journal of Financial Economics 3: 305-60.

Krishnamurthy, Arvind, and Annette Vissing-Jorgensen. 2011. "The Effects of Quantitative Easing on Interest Rates: Channels and Implications for Policy." Brookings Papers on Economic Activity, Fall, 215-265.

Patton, Andrew J., and Tarun Ramadorai. 2013. "On the High-Frequency Dynamics of Hedge Fund Risk Exposures." Journal of Finance 68, no. 2: 597-635.

Rauh, Joshua D. 2009. "Risk Shifting versus Risk Management: Investment Policy in Corporate Pension Plans." Review of Financial Studies 22, no. 7: 2687-733. 
Stein, Jeremy C. 2013. "Overheating in Credit Markets: Origins, Measurement, and Policy Responses." Speech at the "Restoring Household Financial Stability after the Great Recession: Why Household Balance Sheets Matter" research symposium sponsored by the Federal Reserve Bank of St. Louis, St. Louis, Missouri.

GENERAL DISCUSSION Richard Cooper was surprised that Gabriel Chodorow-Reich had not considered exchange rates as a possible channel by which monetary policy might influence the economy. He pointed out that in most countries, though perhaps not the United States, the exchange rate may be the most significant channel influenced by monetary policy. Inside the United States, it is probably not an important direct influence, since money market mutual funds and life insurance companies are not allowed to take extensive open currency positions, but he could imagine an indirect effect through the stock prices of firms with international exposure, as well effects on pension funds and other investors that the regulatory constraints do not touch.

William Brainard thought the author offered a nice definition of the point where the incentives of the managers may not align perfectly with the objectives of shareholders and debt holders. However, in the case of households, he thought it was unclear how one could talk about that divergence. It seemed less unclear in the case of money market funds, particularly so-called convenience funds that serve the interest of firms with stock funds and brokerage service, but there it seemed to Brainard unclear that there was any divergence between the interests of the owner and those of the person with the incentive to reach for yield.

Robert Hall observed that the paper took a narrow view of the impact of QE, namely that it affected the economy mainly by lowering long-term real interest rates. He felt it was equally fair to assume that it affected the equity risk premium, the consequences of which could be profound though understandably outside the author's scope. He mentioned earlier work by Annette Vissing-Jorgensen and Arvind Krishnamurthy, which had found that even the promise to use a similar type of QE in $2012 \mathrm{had}$ a nearly magical effect in stabilizing euro area financial markets. This would only make sense if the unconventional policy were having some dramatic stabilizing effect on the risk premium. In modern finance, he noted, it is a bedrock principle that stock market changes almost always stem from changes in the discount and not in expected future earnings. The event study in the paper showed the S\&P 500 appreciating in cor- 
respondence with $\mathrm{QE}$, which led him to think there may be much more to the policy than modern finance literature currently suggests. It is a very open topic, because modern finance does not know why risk premiums change so much, only that they do.

David Romer remarked on the author's finding that flattening the yield curve might reduce the quantity of lending, and confessed that when he tried to understand this in supply-and-demand terms he found himself confused. In his view, the Fed is lowering the term premium by taking on some of the duration risk in the economy, and the effect of this is to stimulate more lending. In addition, underlining the question Brainard had raised, Romer asked the author to comment on the matter of households reaching for yield, since it did not seem to fit naturally into their definition of reaching for yield in terms of divergence of incentives.

Peter Orszag noted that the vast majority of high-yield bonds were not being held on the balance sheets of the banking sector, but instead are distributed throughout markets. That is probably desirable, in Orszag's view, because along with the concern that banks would be reaching for yield, creating distortions or problems later, an equal concern would be the concentration of risk in highly leveraged financial institutions. To the extent that the assets are being held in less leveraged institutions, all the better.

Robert Gordon returned to a thought that discussant Deborah Lucas had touched on in her comment, namely quantitative rationing among lenders in the banking system. Although discussions of QE1, QE2, and QE3 tend to look at effects on long-term bond yields, as this paper does, or else on the stock market, or even on the exchange rate, he felt that more discussion is warranted about QE's effects on rationing. Based on personal experience and conversations with mortgage lenders, Gordon said, it was clear to him that the rate at which banks have been rejecting mortgage deals has skyrocketed since the financial crisis and remains extremely high. In his view, the biggest story in the slow recovery is what one might call a quantitative rationing of lending to both corporations and households. $\mathrm{He}$ is convinced that the people getting loans today are, broadly speaking, the ones who need them the least.

Donald Kohn summed up his understanding of discussant Annette Vissing-Jorgensen's view, namely that it is worthwhile to look at households, and if households and relatively unleveraged institutions are taking the risk, that could produce economic instability, because it would have a wealth effect. At the same time, he thought, if those risk-takers are not highly leveraged — and certainly households today have a lot less credit- 
the effect is unlikely to intensify through the financial intermediary system, so it would be much less a financial stability issue than an economic issue. He agreed with Lucas that the new regulation of money market funds is relevant, adding that bank regulations have also changed, including the requirement that they have more capital, and that insurers are now looking at additional regulation by the Fed. All this prompted him to wonder whether the increase in regulation may help explain some of the dampening of effects over time.

Kohn was skeptical about Chodorow-Reich's predictions regarding what will happen after QE is rolled up. The author's view seemed to be that the angry reaction in the summer of 2013 was not very harmful and that even multiplying that impact fourfold would not be very bad. But in Kohn's own view, it has become clear that the reactions to these policies cannot be predicted in a linear fashion, and it would be a mistake to treat the 2013 episode as a harmless stress test.

Laurence Meyer picked up on an important methodological issue raised by Lucas. He rejected the idea that event studies like the author's are not very useful because they focus on such a short window, noting that economists have been doing them for a long time. While one cannot limit the analysis to that window, the window is chosen because it concentrates on the largest impact on rates one could detect. Moreover, the impact should begin to decay immediately afterward, due to asset purchases and sales. Secondly, sometimes rates go in the opposite direction after the window has closed, and quickly rise above the initial level, though he did not think that meant that quantitative easing (QE) increases the rates.

Analysts working in the market have found persistent positive surprises following rate announcements, Meyer said. He suggested that some of these effects might be disentangled by estimating with a term premium equation. In his view, the market's reaching for yield is how monetary policy actually works. No one cares about the funds rate-no one borrows at it - and few people even care about the 10-year rate. In Meyer's view, the Fed's policy simply depresses safe rates and, as a result, pushes people into risky assets. Therefore, the measure of how effective monetary policy is should be what happens to private rates, equities, and the dollar. Up to a certain point, QE is fine, but when it is carried out as aggressively as it has been lately, the Fed needs to start worrying about financial stability risks, because it will trigger concentrated and highly leveraged positions in riskier assets. An unexpected change could cause a rush for the exit and yet more discrete impacts on rates. 
Alan Blinder agreed with Lucas about the size of the event window. If one believes in efficient markets, one chooses a short event window to analyze. But that can lead to an exaggerated measurement of the impact of an event on, say, 10-year bond rates or corporate bond rates if, in the near term, speculative markets tend to overshoot. He acknowledged that choosing a larger window has the disadvantage of making it harder to isolate an event, resulting in a trade-off. But it seemed far from obvious to him that a very short window is generally the right thing to use.

On the same theme, Justin Wolfers asked Lucas to clarify what she meant when she said one should ignore the first few events that ChodorowReich examined. Her argument seemed to be that although there was a lot going on at that time, the 30-minute window was so short that there was little going on. Or did she mean that since the markets were behaving strangely, one should not listen to them?

In response, Lucas said that although the only significant thing happening during that short window was the Fed's announcement, so much was changing so quickly in the market in the background that it would be hard to interpret the reaction. For example, there were the TARP events and other bailouts, and each announcement was being interpreted in light of the then huge risk premiums. All of this made it hard for Lucas to believe that the reaction to monetary policy at that moment was something one could extrapolate into the future. Returning to Blinder's question, she believed those early events did not have a very long horizon. Although she did not think there was no risk in the future or even now, for the period of the study, when risk premiums were unusually elevated, she thought the actual risk was small. The key question in her view was which period of time one ought to be examining.

Vissing-Jorgenson also responded to Wolfers' query. She said the paper contained data that made it appear as though the Fed's forward guidance caused the stock market to fall upon the announcement, but in reality the event window was so narrow that it misstated the effect. Intra-day data for that day showed that the Dow rose substantially within the first few hours of the announcement. She suggested that the authors use windows of at least two hours' duration and noted that many economists recommend examining changes over periods as long as several days.

Responding to Orszag's comment about the banks' responses to changes in the yield curve, Vissing-Jorgensen mentioned recent work by Samuel Hanson and Jeremy Stein. They document that changes in monetary policy have surprisingly large effects on long-term bond rates and argue that this 
is due to banks' reaching for duration in response to lower short rates. This also suggests that when one flattens the yield curve, banks will do less of this. Referring to Romer's earlier puzzlement about the supply and demand pattern, she said it seemed to her that for banks it is the price incentive that is likely to dominate. If the Fed policy takes away the profitability of supplying long-term loans funded with short-term liabilities, the banks are going to do less of this maturity transformation.

Gabriel Chodorow-Reich responded first to the issue raised by Lucas and others about event studies and the right window length. He agreed with Lucas that a lot else was going on during this period, but reiterated that to know how the market is reacting to monetary policy alone an important tool is to look at a narrow window, when other things are not happening. There is very heavy trading around FOMC announcements. At least by 2013, the large financial institutions would have learned whether there was a differential effect on life insurers' response to unconventional policy. If they had learned that life insurer stock prices tended to fall on expansionary announcements and then bounce back, they would surely be making the effort to arbitrage it. Another reason to choose a 30-minute window, he said, is that the FOMC announcements are made at press conferences where additional news comes out and sometimes initial confusion needs to be cleared away. Matching the press conference timing allows one to be very precise about what the market is reacting to.

Chodorow-Reich agreed with Vissing-Jorgensen that his general conclusions from the study were relatively sanguine about large financial institutions. The response of other parts of the economy to unconventional policy might pose serious implications for financial stability, but that would need to be addressed in a different study. The market's response to forward guidance, he agreed, was often confused. In fact, the response of the 5-year Treasury and the response of the S\&P 500 moved in opposite directions on the announcement date studied, and then they converged after that.

In response to the question whether risk premiums should be distinguished in the event studies from physical measures, he said he was sympathetic to the concern and it was one of the reasons he compared average non-financial firms in the S\&P 500. If the only change in response to announcements is in the market price of risk, that should move the S\&P 500 , but if there is additional movement in life insurer stock prices, that suggests that something beyond the price of risk was involved. 
Regarding the way money market funds reacted, Chodorow-Reich agreed with those who pointed out that new regulations should have affected their behavior. His paper looked at a change in regulation in 2010, and from this he concluded that regulatory changes were a likely reason why there was less reaching for yield by money market funds than one would have expected. He also agreed with those who suggested that reaching for yield is a good thing. Here he pointed to the "theory of the second best," which is that when there is too much risk aversion and too little risk taking in an economy, if something can encourage some firms to take on more risk, that may well be welfare improving. 
